\title{
Integrative genomics analysis identifies $A C V R 1 B$ as a candidate causal gene of emphysema distribution in non-alpha 1-antitrypsin deficient smokers
}

Adel Boueiz ${ }^{1,2}$, Robert Chase ${ }^{1}$, Andrew Lamb ${ }^{1}$, Sool Lee ${ }^{1}$, Zun Zar Chi Naing ${ }^{1}$, Michael H. Cho $^{1,2}$, Margaret M. Parker ${ }^{1}$, Craig P. Hersh ${ }^{1,2}$, James D. Crapo ${ }^{3}$, Andrew B. Stergachis ${ }^{4}$, Ruth Tal-Singer ${ }^{5}$, Dawn L. DeMeo ${ }^{1,2}$, Edwin K. Silverman ${ }^{1,2}$, Xiaobo Zhou ${ }^{1,2}$, Peter J. Castaldi $^{1,6}$, for the COPDGene investigators.

${ }^{1}$ Channing Division of Network Medicine, Brigham and Women's Hospital, Harvard Medical School, Boston, MA, 02115, USA; ${ }^{2}$ Pulmonary and Critical Care Medicine, Brigham and Women's Hospital, Harvard Medical School, Boston, MA, 02115, USA; ${ }^{3}$ Pulmonary Medicine, National Jewish Health, Denver, CO, 80206, USA; ${ }^{4}$ Division of Genetics, Brigham and Women's Hospital, Harvard Medical School, Boston, MA, 02115, USA; ${ }^{5}$ GSK, King of Prussia, 19406, PA; ${ }^{6}$ General Medicine and Primary Care, Brigham and Women's Hospital, Harvard Medical School, Boston, MA, 02115, USA.

Corresponding Author: Peter J. Castaldi, MD, MSc, Channing Division of Network Medicine, Brigham and Women's Hospital, 181 Longwood Avenue, Boston, MA, 02115, Email: repjc@ channing.harvard.edu

Authors' email addresses: Adel Boueiz (aelboueiz@partners.org), Robert Chase (rerpc@ channing.harvard.edu), Andrew Lamb (andrewelamb@gmail.com), Sool Lee (resle@channing.harvard.edu), Zun Zar Chi Naing (rezcn@channing.harvard.edu), Michael H. Cho (remhc@ channing.harvard.edu), Margaret M. Parker (rempa@ channing.harvard.edu), Craig P. Hersh (craig.hersh@ channing.harvard.edu), James D. Crapo (CrapoJ@ njhealth.org), Andrew B. Stergachis (astergachis@partners.org), Ruth Tal-Singer (Tal-Singer@gsk.com), Dawn L. DeMeo (redld@channing.harvard.edu), Edwin K. Silverman (reeks@channing.harvard.edu), Xiaobo Zhou (rexiz@channing.harvard.edu), Peter J. Castaldi (repjc@channing.harvard.edu) 


\section{ABSTRACT}

Background: Several genetic risk loci associated with emphysema apico-basal distribution (EABD) have been identified through genome-wide association studies (GWAS), but the biological functions of these variants are unknown. To characterize gene regulatory functions of EABD-associated variants, we integrated EABD GWAS results with 1) a multi-tissue panel of expression quantitative trait loci (eQTL) from subjects with COPD and the GTEx project and 2) epigenomic marks from 127 cell types in the Roadmap Epigenomics project. Functional validation was performed for a variant near $A C V R 1 B$.

Results: SNPs from 168 loci with P-values $<5 \times 10^{-5}$ in the largest GWAS meta-analysis of EABD (Boueiz A. et al, AJRCCM 2017) were analyzed. 54 loci overlapped eQTL regions from our multi-tissue panel, and 7 of these loci showed a high probability of harboring a single, shared GWAS and eQTL causal variant (colocalization posterior probability $\geq 0.9$ ). 17 cell types exhibited greater than expected overlap between EABD loci and DNase-I hypersensitive peaks, DNaseI hotspots, enhancer marks, or digital DNaseI footprints (permutation P-value $<0.05$ ), with the strongest enrichment observed in $\mathrm{CD} 4^{+}, \mathrm{CD}^{+}$, and regulatory $\mathrm{T}$ cells. A region near $A C V R 1 B$ demonstrated significant colocalization with a lung eQTL and overlapped DNase-I hypersensitive regions in multiple cell types, and reporter assays in human bronchial epithelial cells confirmed allele-specific regulatory activity for the lead variant, rs 7962469.

Conclusions: Integrative analysis highlights candidate causal genes, regulatory variants, and cell types that may contribute to the pathogenesis of emphysema distribution. These findings will enable more accurate functional validation studies and better understanding of emphysema distribution biology.

Keywords: Integrative genomics; Emphysema; Emphysema distribution; Chronic obstructive pulmonary disease. 


\section{BACKGROUND}

Chronic obstructive pulmonary disease (COPD) is a clinical syndrome with multiple, distinct clinical manifestations including the pathologic loss of lung tissue, i.e. emphysema. The phenotypic variability of COPD has prognostic and therapeutic implications [1-3]. Among patients with emphysema, patterns of lung destruction are often asymmetric [4], and this regional heterogeneity is an important factor in the severity of airflow limitation, disease progression, and the response to lung volume reduction procedures [5-9]. A recent genomewide association study (GWAS) has identified five genomic loci associated with emphysema apico-basal distribution (EABD) in smokers without alpha-1 antitrypsin deficiency (4q13 near SOWAHB, 4q31 near HHIP, 8q24 near TRAPPC9, 10p12 near KIAA1462, and 15q25 near CHRNA5) [10]. These loci explain a small proportion of the estimated heritability of EABD, indicating that many more true associations have not yet been identified. In addition, the functional mechanisms of EABD causal variants have not yet been described.

GWAS variants tend to be located in regions of strong linkage disequilibrium (LD), making it difficult to identify the causal variant (or variants) in these regions from genetic association alone. In addition, GWAS-identified regions are frequently located in non-coding DNA and predominantly affect gene expression rather than directly affecting protein structure. This is supported by the observation that GWAS variants are enriched in regulatory domains, including enhancers and regions of open chromatin [11, 12]. We hypothesized that a number of EABD loci regulate gene expression and are located within genomic regions characterized by DNase-I hypersensitivity, enhancer activity, and transcription-factor binding. To test this hypothesis, we performed comprehensive fine-mapping of EABDassociated loci by integrating GWAS results with a large compendium of multi-tissue eQTL and cell-based epigenetic marks. This analysis identifies 7 high-confidence EABD- 
associated, gene regulatory loci in 42 tissues, and it implicates 17 cell types as likely to participate in EABD pathogenesis, with the strongest enrichment observed for T-cell subsets.

\section{RESULTS}

\section{Characteristics of study participants included in the analysis}

A previously published GWAS was performed using data from 6,215 non-Hispanic white and 2,955 African-American subjects from COPDGene, 1,538 subjects from ECLIPSE, and 824 subjects from GenKOLS with complete phenotype and genotype data (Boueiz A. et al, AJRCCM 2017). The characteristics of these 11,532 subjects are shown in Table 1S, and the characteristics of the 385 COPDGene NHW subjects with available RNA-seq eQTL data are shown in Table $2 \mathrm{~S}$.

\section{Emphysema distribution GWAS signals colocalize with eQTLS}

From the whole blood eQTL of the 385 COPDGene subjects, significant associations at $10 \%$ FDR were identified for 745,067 unique cis-eQTL SNP genotypes associated with the expression level of 17,187 unique transcripts (including protein coding genes, long noncoding RNA, and antisense transcripts) (Table 3S). These eQTLs were analyzed along with the multi-tissue GTEx eQTL data for a total number of unique cis-eQTL SNPs per tissue ranging between 129,647 (uterus) and 1,351,125 (thyroid) and unique eQTL transcripts per tissue ranging between 6,452 (uterus) and 27,618 (testis). The workflow of the GWAS-eQTL integration analysis and results are summarized in Figure 1.

Fifty-four genomic loci were associated with both local gene expression and emphysema distribution at FDR $10 \%$, representing $32.1 \%(54 / 168)$ of the total number of candidate EABD-associated loci (GWAS P-value $<5 \times 10^{-5}$ ). Given that overlap of GWAS 
and eQTL signals may occur by chance, a Bayesian test for colocalization was performed to distinguish overlap due to shared causal variants versus chance overlap. $13.1 \%(22 / 168)$ of candidate EABD loci had a reasonable likelihood (>50\%) of harboring a shared causal variant for emphysema distribution and eQTL, and 4.2\% of loci had a high likelihood (>90\%) of harboring a shared causal variant (Table 1), including two regions that harbored genetic variants affecting the expression of $A C V R I B$ and $M E I$ in lung tissue (Figure 2). The complete set of colocalization results can be viewed interactively at https://cdnm.shinyapps.io/eabd_eqtlcolocalization/.

\section{Emphysema distribution-associated GWAS loci are enriched in T-cell subsets}

To quantify the overlap between EABD-associated loci and epigenomic marks in cell types, we investigated whether candidate EABD-associated loci are enriched in gene regulatory regions identified by large scale functional studies performed by the ENCODE and Roadmap Epigenomics consortia [13, 14]. The four types of epigenomic marks that we studied span 39 to 127 diverse cell types and cover on average $0.44 \%$ to $2.87 \%$ of the genome per cell type (Table 4S). Figure 3 illustrates the workflow for the integrative analysis of GWAS and epigenomic marks.

Forty-five percent of EABD loci (76/168) overlapped at least one of the four studied epigenomic annotations in at least one cell type. Among those, 48 loci overlapped DHS peaks, 54 overlapped DHS hotspots, 60 overlapped enhancer marks, and 26 overlapped DNaseI footprints $(28.6 \%, 32.1 \%, 35.7 \%$, and $15.5 \%$ of EABD loci, respectively).

As with eQTL, some proportion of overlap between EABD loci and regulatory annotations may be due to chance rather than a causal link between the regulatory activity of a locus and its association to emphysema distribution. To better distinguish chance versus causal overlaps, we applied a previously published permutation approach that provides an 
estimate of the overall enrichment of GWAS loci in regulatory regions within a given cell type as well as a locus-specific score [15]. As illustrated in Figure 4, a total of 17 different cell types exhibited evidence of enrichment of EABD loci (Permutation p-value <0.05) in at least one set of epigenomic marks, with the most significant enrichment observed for CD4 ${ }^{+}$, $\mathrm{CD}^{+}$, and regulatory $\mathrm{T}$ cells. Prioritizing loci by cell type enrichment $\mathrm{P}$-values $<0.05$ and overlap locus scores in the lowest $20 \%$ of the overall locus score distribution for each epigenomic mark identified, 21 loci $(12.5 \%$ of the EABD GWAS loci) in 17 different cell types overlapped at least one of the annotations (Table 2). The complete set of results can be viewed at https://cdnm.shinyapps.io/eabd gwas roadmap goshifter/.

\section{Overlaps between EABD GWAS loci, eQTL, and epigenomic marks}

Forty-four percent of EABD GWAS-eQTL loci (24/54) also overlapped at least one of the epigenomic marks in at least one cell type (Table 3). Two of these loci (rs12914385 on chromosome 15 (CHRNA5) and rs17471079 on chromosome 13 (STK24)) had a GWASeQTL colocalization P-value $\geq 0.5$, cell type epigenomic enrichment P-values $<0.05$, and high priority locus scores.

\section{Functional validation of the rs7962469 variant near ACVR1B}

Assuming that GWAS regions that colocalize with lung eQTLs may be more likely to play a causal role in emphysema distribution, we focused on the regions near the ACVRIB and the $M E I$ genes for further functional prioritization. The pattern of association near $M E I$ was nearly linear over a broad genomic region of high LD, making the identification of a single causal variant challenging. This, in combination with evidence of colocalization of rs7962469 with DNaseI hypersensitive regions in multiple cell types, led us to prioritize the region near $A C V R I B$ for functional characterization. We used the PICS method to identify 
the $95 \%$ credible set of SNPs responsible for the GWAS association near ACVRIB, and the causal probability for rs7962469 was estimated to be $96 \%$. Based on these results, we tested for an allelic expression effect of rs7962469 in human bronchial epithelial (16HBE) cells, and we observed that the $G$ variant of rs7962469 has a significantly decreased expression relative to the A variant (Figure 5). The rs $7962469 \mathrm{G}$ variant has previously been shown to be associated with COPD susceptibility (OR: 1.13, SE: 1.03; GWAS P-value: 0.002) [16] and with upper lobe emphysema predominance (effect size: 0.06, SE: 0.01, GWAS P-value: $\left.1.7 \times 10^{-5}\right)[10]$.

\section{DISCUSSION}

Using a multi-cohort GWAS of EABD, multi-tissue eQTL from 45 tissues, and epigenomic marks from 127 cell types, we performed an integrated genetic-epigenomic study to further our functional understanding of common variants associated with this specific manifestation of COPD. eQTL colocalization analysis identified strong evidence of a shared causal variant responsible for observed GWAS and eQTL associations in 7 distinct loci in multiple tissues. GWAS-epigenomic mark enrichment was observed for 17 cell types, with the strongest enrichment in $\mathrm{CD}^{+}, \mathrm{CD}^{+}$, and regulatory $\mathrm{T}$ cells. A region near the promoter of the $A C V R I B$ gene demonstrated strong colocalization in lung eQTL data and lies within a DNase-I hypersensitive region that is active in multiple cell types. Reporter assays confirmed allele-specific regulatory activity for the EABD-associated variant, rs7962469, near ACVRIB with the $G$ allele associated with decreased reporter gene expression, increased COPD susceptibility, and upper lobe emphysema predominance.

Efforts to understand how genetic variation contributes to common diseases increasingly focus on the regulation of gene expression [17-19]. The enrichment of cis-eQTL 
SNPs has been demonstrated for GWAS-identified loci in COPD [20], and EABD GWASeQTL overlap has been previously reported for EABD [21]. With the use of RNA-seq in multiple tissues in GTEx and in blood from subjects with COPD from the COPDGene study, the current study confirmed the previously reported EABD GWAS-eQTL overlap at the $15 \mathrm{q} 25$ locus with formal colocalization testing and added evidence for genetic control of gene expression at 12 other emphysema distribution-associated loci.

GWAS-identified loci for some phenotypes are enriched for regulatory marks in tissues that are relevant to the phenotype [21-25]. In the case of emphysema distribution, we observed GWAS-regulatory region overlap in multiple tissue and cell types, highlighting the biological complexity of emphysema and the fact that a significant amount of the regulatory genome is active across multiple tissues and cell types. While some disease loci lie within cell type-specific regulatory regions [26], our results are consistent with Boyle et al.'s work that provided evidence that many complex traits are driven by regulatory variants that tend to be active across many cell types and tissues [27].

Because most GWAS loci discovered to date lie outside of coding regions, it is likely that these loci affect gene regulation. $32.1 \%$ of the EABD-associated GWAS loci overlap with eQTL and $45.2 \%$ overlap with epigenomic annotations. However, our analysis indicates that a significant proportion of these overlaps may be due to chance, because only $13.1 \%$ of candidate EABD regions overlapped an eQTL with a colocalization probability $\geq 0.5$, and only $12.5 \%$ overlapped an epigenomic mark with a high priority locus score. Furthermore, only $1.2 \%$ (2 loci) had a GWAS-eQTL colocalization P-value $\geq 0.5$, cell type epigenomic enrichment P-values $<0.05$, and high priority locus scores. Our observation that a notable proportion of observed GWAS overlaps with regulatory signals may be due to chance is consistent with previous observations in multiple sclerosis [28]. It is likely that this 
observation reflects the high prevalence of regulatory activity in the genome. However, the enrichment methods that we used suffer from important limitations. The Bayesian colocalization method assumes the presence of only one causal variant in a given locus for both GWAS and eQTL signals; this assumption reduces the accuracy of results when the locus contains multiple causal variants $[17,29]$. The GoShifter method penalizes regions that are dense in epigenomic annotations and may therefore decrease the power of causal variant identification [15].

It is also interesting to consider the proportion of GWAS signals for which no regulatory overlaps were identified. These instances of non-overlap could be due to false positive GWAS associations at the reduced stringency levels used for this analysis, limited power of the included eQTL analyses [17], limited assessment of the dynamic nature of epigenomic marks in included cell type data, and lack of representation of relevant tissues and cell types for emphysema in GTEx and the Roadmap Epigenomics project, respectively. It is also possible that EABD causal variants affect aspects of gene regulation not observed in our data, such as splicing or post-transcriptional regulation [17].

It has been recognized for many years that emphysema often has a predilection for the upper lobes and subpleural areas in non-alpha-1 antitrypsin deficient smokers $[10,30]$. The cause for these regional differences in emphysema distribution is not well understood but has been attributed to regional differences in perfusion, transit time of leukocytes, clearance of deposited dust, mechanical stress and pleural pressure [30-33]. This study provides compelling evidence to support a causal role for the adaptive immune response in EABD, with the strongest enrichment of EABD loci in regulatory activity observed in $\mathrm{CD} 4^{+}, \mathrm{CD} 8^{+}$, and regulatory T cells. Furthermore, based on the results of the genomics integrative analysis and the confirmatory reporter assay, our study prioritized the rs7962469 variant, near the $A C V R 1 B$ gene, as a candidate causal variant in emphysema distribution. 
$A C V R 1 B$, also known as $A L K-4$, acts as a transducer of activin-like ligands that are growth and differentiation factors belonging to the transforming growth factor- $\beta$ (TGF- $\beta$ ) superfamily of signaling proteins. Although $A C V R 1 B$ has not previously been associated with emphysema distribution, prior genetic studies have demonstrated an association of gene polymorphisms of the TGF- $\beta$ superfamily with COPD $[34,35]$. A genome-wide association meta-analysis of 3,497 subjects with severe COPD identified a genome-wide significant association with a locus previously reported to affect the gene expression of $T G F B 2$ [16]. In addition, TGFB2 expression levels were reduced in a set of Lung Tissue Research Consortium COPD lung tissue samples compared with controls [16]. A network analysis incorporating COPD GWAS and protein-protein interaction (PPI) data included ACVRIB gene in a 10 gene consensus network module associated with COPD case-control status [36]. In addition, differential expression of $A C V R I B$ has been found in the epithelial cells of a subset of smokers with lung cancer and in bone marrow micro-metastases from lung cancer patients $[37,38]$. More work is warranted to elucidate the role of $A C V R I B$ in COPD and emphysema.

The strengths of this study are 1) the use of comprehensive compendia of eQTL and epigenetic marks in multiple tissues and cell types for a novel COPD-related phenotype, 2) application of Bayesian and permutation-based methods to assess the significance of observed overlaps accounting for the genomic abundance of candidate eQTLs and epigenomic annotations, and 3) functional validation and demonstration of allele-specific enhancer activity for a candidate causal variant near $A C V R I B$ prioritized by this integrative method.

This study also has important limitations. First, we limited our analysis to cis-eQTLs, excluding other classes of gene regulatory variants including trans-eQTLs, isoform ratio 
QTLs, and variants implicated by allele-specific expression analyses. Future studies will be strengthened by the inclusion of these emerging features of eQTL studies [39, 40]. Second, the colocalization and enrichment methods that we used have limitations. The colocalization method does not account for multiple independent signals, and the GoShifter approach is biased against regions that are dense in epigenomic annotations and may therefore decrease the power of causal variant identification $[15,17,29]$.

\section{CONCLUSION}

This study provides proof of concept for the effectiveness of an approach to leverage multi-tissue compendia of eQTLs and multi-cell compendia of epigenetic marks to refine and characterize functional regulatory GWAS loci. Enrichment analyses implicated a wide range of cells and tissues, emphasizing the importance of having comprehensive compendia of regulatory annotation with respect to tissues, cell types, diseases, and environmental exposures. Based on these integrative analyses, we prioritized and functionally validated a COPD and emphysema-associated variant involved in TGF- $\beta$ signaling.

\section{MATERIALS AND METHODS}

\section{Study populations}

We analyzed 11,532 non-alpha-1 antitrypsin deficient current and former smokers with complete genotype and CT densitometry data from four cohorts: The Genetic Epidemiology of COPD study non-Hispanic whites (COPDGene NHW), COPDGene African-Americans (COPDGene AA), the Genetics of Chronic Obstructive Lung Disease (GenKOLS) and the Evaluation of COPD Longitudinally to Identify Predictive Surrogate Endpoints study (ECLIPSE). Detailed descriptions including study populations, genotyping quality control and genotyping imputation have been previously published $[10,41]$. 


\section{CT measurements}

Quantitative assessment of emphysema was performed using 3D SLICER density mask analysis (www.chestimagingplatform.org) to determine the percentage of lung voxels with attenuation lower than -950 Hounsfield units (\%LAA-950) at maximal inspiration [42]. From these measurements, two correlated but complementary measures of emphysema distribution were constructed: 1) the difference between upper third and lower third emphysema (diff950) and 2) the ratio of upper third to lower third emphysema (ratio950) [10]. A rank-based inverse normal transformation was applied to both phenotypes to reduce the impact of outliers and deviations from normality [10]. In this current study, given that ratio950 had a higher heritability and was associated with more genome-wide significant signals compared to diff950 [10], we performed fine mapping of ratio950-associated variants.

\section{Peripheral blood gene expression}

385 NHW subjects from the COPDGene study with completed peripheral blood RNA sequencing (RNA-seq) data were analyzed. All samples had RNA integrity number $>7$ and RNA concentration $\geq 25 \mu \mathrm{g} / \mu \mathrm{l}$ (COPDGene Phase I dataset, January 6, 2017).

RNA isolation and quality control: Total RNA was extracted from PAXgene Blood RNA tubes using the Qiagen PreAnalytiX PAXgene Blood miRNA Kit. The extraction protocol was performed either manually or with the Qiagen QIAcube extraction robot.

cDNA library preparation and sequencing: Globin reduction and cDNA library preparation for total RNA was performed with the Illumina TruSeq Stranded Total RNA with Ribo-Zero Globin kit. Libraries were pooled and 75bp paired end reads were generated on the Illumina HiSeq2000 platform. Samples were sequenced to an average depth of 20 million reads. 
Read alignment, expression quantification, and sequencing quality control: Reads were trimmed of the Truseq adapters using Skewer [43] with default parameters. Trimmed reads were aligned to GRCH38 genome using STAR [44]. Gene level counts were generated using RSubreads with the Ensemble GTF (version 81). Quality control was performed using the Fastqc [45] and RNA-SeQC [46] programs. Samples were included for subsequent analysis if they had >10 million reads, $>80 \%$ of reads mapped, XIST and Y chromosome expression consistent with reported gender, $<10 \%$ of $\mathrm{R} 1$ reads in the sense orientation, Pearson correlation $\geq 0.9$ with other samples in the same library prep batch, and concordant genotype calls between RNA reads and DNA genotyping.

cis-eQTL analysis: Transcript-level expression count data were normalized for library size using the trimmed mean of $\mathrm{M}$ values method and then inverse normal transformed [47]. eQTL associations were tested for bi-allelic, autosomal SNPs with minor allele frequency $(\mathrm{MAF})>0.05$ and mapping to a dbSNP 142 Reference SNP number. cis-eQTL analysis was performed for all SNPs within one megabase of the target gene using Matrix eQTL with a linear model adjusting for age, gender, library prep batch, 3 principal components of genetic ancestry, and 35 PEER factors of gene expression [48]. A total of 5,815,008 SNPs were tested for association with 27,277 transcripts. The threshold for significance was a false discovery rate (FDR) 10\%, using the FDR procedure implemented in Matrix eQTL [49].

\section{eQTL-emphysema distribution GWAS colocalization analysis}

We integrated emphysema distribution GWAS loci with multi-tissue eQTL data from the Genotype-Tissue Expression (GTEx) project (version 6) [10] (Download site: http://www.gtexportal.org/home/datasets; Date of download: November 18, 2015) and whole blood eQTL from 385 COPDGene NHW subjects. GWAS eQTL integration was performed as previously described [21]. Briefly, for each set of eQTL results, GWAS results were 
filtered to include only SNPs with a significant eQTL association at FDR 10\%. In this reduced set of GWAS results, q-values were calculated using the procedure of Storey et al. for the GWAS P-values [50], and SNPs significant in both the eQTL and GWAS analyses at FDR $10 \%$ were retained. For each independent association, Bayesian colocalization tests were performed for all SNPs within a $250 \mathrm{~kb}$ window of the lead GWAS variant at that locus to quantify the probability that the GWAS and eQTL associations were due to a single, shared causal variant [29]. This probability corresponds to the $\mathrm{PP}_{4}$ number described in the original publication. The workflow of this GWAS-eQTL integration analysis is summarized in Table 2.

\section{Enrichment in tissue-/cell type-specific chromatin states}

Genetic variants associated with complex diseases have been shown to overlap regulatory enhancer elements $[11,12]$. Based on this finding, we quantified the overlap between emphysema distribution GWAS SNPs $\left(\mathrm{P}\right.$-value $\left.<5 \times 10^{-5}\right)$ and regulatory elements identified in the Roadmap Epigenomics project (Release 9) [51]. For the 127 Roadmap cell types, we downloaded ChromImpute imputed annotations that provide the most comprehensive human regulatory region annotation to date for large-scale experimental mapping of epigenomic information [52]. We analyzed ChromImpute DNase-I hypersensitive peaks and ChromImpute enhancer marks (defined as chromatin states 13 through 18) for all 127 cell types with available data. We also examined DNase-I hypersensitive hotspots that were available for 39 Roadmap cell types. Hotspots are broader regions of DNaseI hypersensitivity encompassing DNase peaks. The hotspot identification algorithm has been previously described [53]. We also analyzed digital DNaseI footprints (DGF) data from 42 uniformly processed cell types in Roadmap. DNaseI footprints are coverage troughs in deeply sequenced DNaseI hypersensitivity data that represent narrow genomic regions shielded from 
DNaseI digestion because of transcription factors, and thus represent likely transcription factor binding sites (TFBS).

DHS ChromImpute peaks were downloaded from

http://egg2.wustl.edu/roadmap/data/byFileType/peaks/consolidatedImputed/narrowPeak/ on

July 13, 2016. DHS hotspots were downloaded from

http://egg2.wustl.edu/roadmap/data/byFileType/peaks/consolidated/broadPeak/DNase/ on

February 20, 2015. Enhancer marks were downloaded from

http://egg2.wustl.edu/roadmap/data/byFileType/chromhmmSegmentations/ChmmModels/im

puted12marks/jointModel/final/ on Dec 23, 2015. DGF were downloaded from

http://egg2.wustl.edu/roadmap/data/byDataType/dgfootprints/ on July 13, 2016.

To determine the extent of GWAS-epigenomic annotation overlap, we identified independent emphysema distribution GWAS signals at $\mathrm{P}$-value $<5 \times 10^{-5}$ within $1 \mathrm{MB}$ windows. We then used Genomic Annotation Shifter (GoShifter) to calculate the enrichment for these variants in Roadmap annotations (DHS, enhancer marks, DGF) [15]. This method uses a local permutation strategy to account for the local density of a given epigenomic mark and generates a score for each locus that can be used to prioritize loci where the overlap between a SNP and an annotation is particularly informative. 1,000 permutations were performed using LD information from the 1,000 Genomes EUR population with an $\mathrm{r}^{2}$ threshold of 0.8 . Overlaps in the lowest $20 \%$ of locus score distributions and with a cell type enrichment P-value $<0.05$ were considered for further analysis (Table 3).

\section{Shiny applications}

Searchable tables of the formal metrics, results, and locuszoom plots for each genomic region was compiled and displayed using the $\mathrm{R}$ web framework shiny (http://shiny.rstudio.com/) and are available to the public as companion sites for this paper 
(https://cdnm.shinyapps.io/eabd_eqtlcolocalization/

(GWAS-eQTL)

and

https://cdnm.shinyapps.io/eabd_gwas_roadmap_goshifter/(GWAS-epigenomic annotations)).

\section{Probabilistic Identification of Causal SNPs - rs7962469}

The online Probabilistic Identification of Causal SNPs (PICS) algorithm is a fine mapping algorithm that calculates the probability that an individual SNP is a causal variant given the haplotype structure and observed pattern of association at the locus (https://pubs.broadinstitute.org/pubs/finemapping/pics.php) [54]. We used this algorithm to generate the $95 \%$ credible SNP set for the GWAS association identified in the region near the ACVR1B gene.

\section{Luciferase reporter assay - rs7962469}

Two 500 base-pair long genomic segments including rs7962469 were obtained from Human Bronchial Epithelial (16HBE) cells heterozygous at rs7962469 and cloned into the sites of XhoI and BglII of a pGL4.23[luc2/minP] vector. Each luciferase construct was cotransfected with TK-Renilla, a luciferase control reporter, in 16HBE cells at $\sim 60-70 \%$ confluency by using Lipofectamine 3000 Reagent (Invitrogen), following the manufacturer's protocol. Each luciferase construct was transfected in triplicate at a concentration of $300 \mathrm{ng}$ per well and the TK-Renilla at $15 \mathrm{ng}$ per well. Empty Luciferase vector, pGL4.23[luc2/minP], was also transfected in triplicates as a control. Promoter activity was quantified forty-eight hours post-transfection using the Dual-Luciferase Reporter Assay System (Promega) according to the manufacturer's protocol. Luminescence signals were captured in a Wallac VICTOR3 1420 plate reader (Perkin Elmer) and normalized by the Renilla luciferase readings for each well. The normalized values for each triplicate were then averaged. All plasmids used were confirmed by sequencing. Independent transfection and 
reporter assays were performed three times. Luciferase activity levels were assessed using Wilcoxon's rank sum test; values were compared with a reference group within an experimental repeat, and results from multiple experiments were included. P-values less than 0.05 were considered significant. 
Table 1. Significant colocalizations of emphysema distribution-associated GWAS variants with eQTL from GTEx and the COPDGene study (colocalization probability $\geq 0.9$ ) ordered by the lead SNP GWAS P-values.

\begin{tabular}{|c|c|c|c|c|c|c|}
\hline Lead SNP & Position & $\begin{array}{c}\text { HUGO } \\
\text { gene } \\
\text { annotation }\end{array}$ & $\begin{array}{l}\text { GWAS } \\
\text { P-value }\end{array}$ & eQTL tissue & $\begin{array}{c}\text { eQTL } \\
\text { Q-value }\end{array}$ & $\begin{array}{c}\text { Colocalization } \\
\text { probability }\end{array}$ \\
\hline rs12914385 & $15: 78898723$ & CHRNA5 & $1.70 \times 10^{-17}$ & Testis & 0.001 & 0.91 \\
\hline \multirow{2}{*}{ rs2645694 } & \multirow{2}{*}{$4: 77833947$} & \multirow{2}{*}{$S O W A H B$} & \multirow{2}{*}{$2.40 \times 10^{-8}$} & Skin: Sun-exposed (Lower leg) & 0.007 & 0.94 \\
\hline & & & & Esophagus: Mucosa & 0.003 & 0.94 \\
\hline rs35500465 & $19: 1158884$ & SBNO2 & $1.80 \times 10^{-6}$ & Esophagus: Mucosa & 0.001 & 0.94 \\
\hline \multirow{3}{*}{ rs5758407 } & \multirow{3}{*}{$22: 42076956$} & \multirow{3}{*}{$M E I 1$} & \multirow{3}{*}{$5.90 \times 10^{-6}$} & Cells: Transformed fibroblasts & $4.47 \times 10^{-18}$ & 0.93 \\
\hline & & & & Lung & $1.59 \times 10^{-11}$ & 0.91 \\
\hline & & & & Adipose: Subcutaneous & $1.53 \times 10^{-9}$ & 0.90 \\
\hline rs17471079 & 13:99168721 & STK24 & $1.10 \times 10^{-5}$ & Artery: Tibial & $1.47 \times 10^{-6}$ & 0.96 \\
\hline rs7962469 & $12: 52348259$ & $A C V R l B$ & $1.70 \times 10^{-5}$ & Lung & 0.0005 & 0.91 \\
\hline rs4468504 & $14: 107122186$ & IGHV3-66 & $2.70 \times 10^{-5}$ & Colon: Transverse & $6.45 \times 10^{-13}$ & 0.91 \\
\hline
\end{tabular}


Table 2. Significant overlaps between emphysema distribution-associated variants and epigenomic annotations (in the lowest $20 \%$ of locus score distributions and with a cell type enrichment $\mathrm{P}$-value $<0.05)$.

\section{A. ChromImpute DNase-I hypersensitive sites}

\begin{tabular}{|c|c|c|c|c|c|c|c|}
\hline Locus SNP & Position & Nearest Gene & $\begin{array}{l}\text { Locus SNP GWAS } \\
\text { P-value }\end{array}$ & Overlap SNP & $\begin{array}{l}\text { Overlap SNP } \\
\text { GWAS P-value }\end{array}$ & Cell type & $\begin{array}{l}\text { Cell type } \\
\text { P-value }\end{array}$ \\
\hline \multirow{5}{*}{ rs12914385 } & \multirow{5}{*}{$15: 78862103$} & \multirow{5}{*}{ CHRNA3 } & \multirow{5}{*}{$1.72 \times 10^{-17}$} & \multirow{5}{*}{ rs8040868 } & \multirow{5}{*}{$1.92 \times 10^{-12}$} & $\begin{array}{l}\text { Primary T helper } 17 \text { cells PMA-I } \\
\text { stimulated; }\end{array}$ & 0.003 \\
\hline & & & & & & $\begin{array}{l}\text { Primary T killer memory cells from } \\
\text { peripheral blood }\end{array}$ & 0.01 \\
\hline & & & & & & $\begin{array}{l}\text { Primary T helper memory cells from } \\
\text { peripheral blood } 1\end{array}$ & 0.02 \\
\hline & & & & & & Primary T helper cells PMA-I stimulated & 0.02 \\
\hline & & & & & & $\begin{array}{l}\text { Primary T helper naive cells from } \\
\text { peripheral blood }\end{array}$ & 0.02 \\
\hline \multirow{5}{*}{ rs141092330 } & \multirow{5}{*}{$7: 17181839$} & \multirow{5}{*}{$A N K M Y 2$} & \multirow{5}{*}{$2.44 \times 10^{-5}$} & \multirow{5}{*}{ rs141092330 } & \multirow{5}{*}{$2.44 \times 10^{-5}$} & $\begin{array}{l}\text { Primary T helper } 17 \text { cells PMA-I } \\
\text { stimulated }\end{array}$ & 0.003 \\
\hline & & & & & & $\begin{array}{l}\text { Primary T killer memory cells from } \\
\text { peripheral blood }\end{array}$ & 0.01 \\
\hline & & & & & & $\begin{array}{l}\text { Primary } \mathrm{T} \text { helper memory cells from } \\
\text { peripheral blood } 1\end{array}$ & 0.02 \\
\hline & & & & & & Primary T helper cells PMA-I stimulated & 0.02 \\
\hline & & & & & & $\begin{array}{l}\text { Primary T helper naive cells from } \\
\text { peripheral blood }\end{array}$ & 0.02 \\
\hline \multirow{5}{*}{ rs142142561 } & \multirow{5}{*}{$15: 100753780$} & \multirow{5}{*}{ ADAMTS17 } & \multirow{5}{*}{$1.60 \times 10^{-5}$} & \multirow{5}{*}{ rs142142561 } & \multirow{5}{*}{$1.60 \times 10^{-5}$} & $\begin{array}{l}\text { Primary T helper } 17 \text { cells PMA-I } \\
\text { stimulated }\end{array}$ & 0.003 \\
\hline & & & & & & $\begin{array}{l}\text { Primary T killer memory cells from } \\
\text { peripheral blood }\end{array}$ & 0.01 \\
\hline & & & & & & $\begin{array}{l}\text { Primary } \mathrm{T} \text { helper memory cells from } \\
\text { peripheral blood } 1\end{array}$ & 0.02 \\
\hline & & & & & & Primary T helper cells PMA-I stimulated & 0.02 \\
\hline & & & & & & $\begin{array}{l}\text { Primary T helper naive cells from } \\
\text { peripheral blood }\end{array}$ & 0.02 \\
\hline rs2466200 & $8: 22810931$ & PIWIL2 & $4.62 \times 10^{-6}$ & rs2466200 & $4.62 \times 10^{-6}$ & $\begin{array}{l}\text { Primary T helper } 17 \text { cells PMA-I } \\
\text { stimulated }\end{array}$ & 0.003 \\
\hline
\end{tabular}




\begin{tabular}{|c|c|c|c|c|c|c|c|}
\hline & & & & & & $\begin{array}{l}\text { Primary T killer memory cells from } \\
\text { peripheral blood }\end{array}$ & 0.01 \\
\hline & & & & & & $\begin{array}{l}\text { Primary } \mathrm{T} \text { helper memory cells from } \\
\text { peripheral blood } 1\end{array}$ & 0.02 \\
\hline & & & & & & Primary T helper cells PMA-I stimulated & 0.02 \\
\hline & & & & & & $\begin{array}{l}\text { Primary T helper naive cells from } \\
\text { peripheral blood }\end{array}$ & 0.02 \\
\hline \multirow{5}{*}{ rs75992165 } & \multirow{5}{*}{$11: 13631045$} & \multirow{5}{*}{ FARl } & \multirow{5}{*}{$2.27 \times 10^{-6}$} & \multirow{5}{*}{ rs75992165 } & \multirow{5}{*}{$2.27 \times 10^{-6}$} & $\begin{array}{l}\text { Primary T helper } 17 \text { cells PMA-I } \\
\text { stimulated }\end{array}$ & 0.003 \\
\hline & & & & & & $\begin{array}{l}\text { Primary T killer memory cells from } \\
\text { peripheral blood }\end{array}$ & 0.01 \\
\hline & & & & & & $\begin{array}{l}\text { Primary } \mathrm{T} \text { helper memory cells from } \\
\text { peripheral blood } 1\end{array}$ & 0.02 \\
\hline & & & & & & Primary T helper cells PMA-I stimulated & 0.02 \\
\hline & & & & & & $\begin{array}{l}\text { Primary T helper naive cells from } \\
\text { peripheral blood }\end{array}$ & 0.02 \\
\hline
\end{tabular}

\section{B. DNase hotspots}

\begin{tabular}{|c|c|c|c|c|c|c|c|}
\hline Locus SNP & Position & Nearest Gene & $\begin{array}{c}\text { Locus SNP } \\
\text { GWAS P-value }\end{array}$ & Overlap SNP & $\begin{array}{l}\text { Overlap SNP GWAS } \\
\text { P-value }\end{array}$ & Cell type & $\begin{array}{l}\text { Cell type } \\
\text { P-value }\end{array}$ \\
\hline \multirow[b]{2}{*}{ rs12914385 } & \multirow[b]{2}{*}{$15: 78862097$} & \multirow[b]{2}{*}{ CHRNA3 } & \multirow[b]{2}{*}{$1.72 \times 10^{-17}$} & \multirow[b]{2}{*}{ rs8040868 } & \multirow[b]{2}{*}{$1.92 \times 10^{-12}$} & Primary T cells from peripheral blood & 0.02 \\
\hline & & & & & & $\begin{array}{l}\text { Primary Natural Killer cells from peripheral } \\
\text { blood }\end{array}$ & 0.04 \\
\hline \multirow{3}{*}{ rs141092330 } & \multirow{3}{*}{ 7:17181846 } & \multirow{3}{*}{$A N K M Y 2$} & \multirow{3}{*}{$2.44 \times 10^{-5}$} & \multirow{3}{*}{ rs141092330 } & \multirow{3}{*}{$2.44 \times 10^{-5}$} & Primary T cells from peripheral blood & 0.02 \\
\hline & & & & & & Small Intestine & 0.04 \\
\hline & & & & & & $\begin{array}{l}\text { Primary Natural Killer cells from peripheral } \\
\text { blood }\end{array}$ & 0.04 \\
\hline \multirow[b]{2}{*}{ rs142142561 } & \multirow[b]{2}{*}{ 15:100753808 } & \multirow[b]{2}{*}{ ADAMTS17 } & \multirow[b]{2}{*}{$1.60 \times 10^{-5}$} & \multirow[b]{2}{*}{ rs142142561 } & \multirow[b]{2}{*}{$1.60 \times 10^{-5}$} & Primary T cells from peripheral blood & 0.02 \\
\hline & & & & & & $\begin{array}{l}\text { Primary Natural Killer cells from peripheral } \\
\text { blood }\end{array}$ & 0.04 \\
\hline rs142822120 & $3: 43769809$ & ABHD5 & $3.28 \times 10^{-5}$ & rs 142822120 & $3.28 \times 10^{-5}$ & Small Intestine & 0.04 \\
\hline rs182017195 & $6: 17573162$ & NUP153 & $4.02 \times 10^{-5}$ & rs77103244 & $4.72 \times 10^{-5}$ & Small Intestine & 0.04 \\
\hline rs2046399 & $8: 9988262$ & MSRA & $3.29 \times 10^{-5}$ & rs2046399 & $3.29 \times 10^{-5}$ & Small Intestine & 0.04 \\
\hline rs75992165 & $11: 13631020$ & FARl & $2.27 \times 10^{-6}$ & rs75992165 & $2.27 \times 10^{-6}$ & Primary T cells from peripheral blood & 0.02 \\
\hline
\end{tabular}




\begin{tabular}{|c|c|c|c|c|c|c|c|}
\hline & & & & & & $\begin{array}{l}\text { Primary Natural Killer cells from peripheral } \\
\text { blood }\end{array}$ & 0.04 \\
\hline rs77808082 & 6:138875121 & NHSL1 & $3.32 \times 10^{-5}$ & rs77808082 & $3.32 \times 10^{-5}$ & Small Intestine & 0.04 \\
\hline
\end{tabular}

\section{ChromImpute enhancer regions (ChromImpute chromatin states 13 through 18)}

\begin{tabular}{|c|c|c|c|c|c|c|c|}
\hline Locus SNP & Position & Gene annotation & $\begin{array}{c}\text { Locus SNP } \\
\text { GWAS P-value }\end{array}$ & Overlap SNP & $\begin{array}{c}\text { Overlap SNP } \\
\text { GWAS P-value }\end{array}$ & Cell type & $\begin{array}{l}\text { Cell type } \\
\text { P-value }\end{array}$ \\
\hline rs13141641 & $4: 145435924$ & $H H I P$ & $6.34 \times 10^{-18}$ & rs1813903 & $1.65 \times 10^{-14}$ & Thymus & 0.03 \\
\hline rs141092330 & $7: 17181789$ & $A N K M Y 2$ & $2.44 \times 10^{-5}$ & rs141092330 & $2.44 \times 10^{-5}$ & Thymus & 0.03 \\
\hline rs 142822120 & $3: 43769780$ & KRBOX1 & $3.28 \times 10^{-5}$ & rs142822120 & $3.28 \times 10^{-5}$ & Fetal Heart & 0.01 \\
\hline rs12408334 & 1:201908397 & LMOD1 & $3.83 \times 10^{-5}$ & rs12408334 & $3.83 \times 10^{-5}$ & ES-WA7 Cell Line & 0.047 \\
\hline rs 1452915 & $7: 134486525$ & $C A L D 1$ & $2.12 \times 10^{-5}$ & rs 28485360 & $2.33 \times 10^{-5}$ & ES-WA7 Cell Line & 0.047 \\
\hline \multirow{2}{*}{ rs 17471079} & \multirow{2}{*}{ 13:99116428 } & \multirow{2}{*}{ STK24 } & \multirow{2}{*}{$1.07 \times 10^{-5}$} & \multirow{2}{*}{ rs17574654 } & \multirow{2}{*}{$3.16 \times 10^{-5}$} & Thymus & 0.03 \\
\hline & & & & & & Fetal Heart & 0.01 \\
\hline rs2046399 & $8: 9988261$ & MSRA & $3.29 \times 10^{-5}$ & rs 1484644 & $3.41 \times 10^{-5}$ & ES-WA7 Cell Line & 0.047 \\
\hline \multirow{2}{*}{ rs2466200 } & \multirow{2}{*}{$8: 22810906$} & \multirow{2}{*}{ CPNE3 } & \multirow{2}{*}{$4.62 \times 10^{-6}$} & \multirow{2}{*}{ rs2466200 } & \multirow{2}{*}{$4.62 \times 10^{-6}$} & Fetal Heart & 0.01 \\
\hline & & & & & & ES-WA7 Cell Line & 0.047 \\
\hline rs56073943 & $14: 94230766$ & PRIMAI & $3.11 \times 10^{-5}$ & rs56073943 & $3.11 \times 10^{-5}$ & ES-WA7 Cell Line & 0.047 \\
\hline rs5995407 & $22: 37640841$ & $R A C 2$ & $1.31 \times 10^{-5}$ & rs5995407 & $1.31 \times 10^{-5}$ & ES-WA7 Cell Line & 0.047 \\
\hline rs6501394 & $17: 68424096$ & KCNJ16 & $5.34 \times 10^{-6}$ & rs6501394 & $5.34 \times 10^{-6}$ & ES-WA7 Cell Line & 0.047 \\
\hline rs6744412 & $2: 106214065$ & FHL2 & $2.16 \times 10^{-5}$ & rs6744412 & $2.16 \times 10^{-5}$ & Thymus & 0.03 \\
\hline rs72690469 & $8: 87474571$ & CPNE3 & $7.77 \times 10^{-6}$ & rs72690446 & $3.79 \times 10^{-5}$ & Fetal Heart & 0.01 \\
\hline rs73226109 & 21:42661694 & $F A M 3 B$ & $1.82 \times 10^{-5}$ & rs73226109 & $1.82 \times 10^{-5}$ & Thymus & 0.03 \\
\hline rs966081 & 13:74864605 & $K L F 12$ & $8.45 \times 10^{-6}$ & rs966081 & $8.45 \times 10^{-6}$ & Fetal Heart & 0.01 \\
\hline
\end{tabular}




\section{DNaseI footprints}

\begin{tabular}{|c|c|c|c|c|c|c|c|}
\hline Locus SNP & Position & Gene annotation & $\begin{array}{c}\text { Locus SNP GWAS } \\
\text { P-value }\end{array}$ & Overlap SNP & $\begin{array}{c}\text { Overlap SNP } \\
\text { GWAS P-value }\end{array}$ & Cell type & $\begin{array}{c}\text { Cell type } \\
\text { P-value }\end{array}$ \\
\hline \multirow{2}{*}{ rs12914385 } & \multirow{2}{*}{$15: 78862436$} & \multirow{2}{*}{ CHRNA3 } & \multirow{2}{*}{$1.72 \times 10^{-17}$} & \multirow{2}{*}{ rs8040868 } & \multirow{2}{*}{$1.92 \times 10^{-12}$} & Fetal skin fibroblast & 0.03 \\
\hline & & & & & & Fetal placenta & 0.04 \\
\hline rs141092330 & $7: 17182180$ & $A N K M Y 2$ & $2.44 \times 10^{-5}$ & rs141092330 & $2.44 \times 10^{-5}$ & Fetal placenta & 0.04 \\
\hline rs1452915 & $7: 134486916$ & CALD1 & $2.12 \times 10^{-5}$ & rs28485360 & $2.33 \times 10^{-5}$ & iPS 19.11 & 0.03 \\
\hline rs79958058 & $3: 133597788$ & $R A B 6 B$ & $3.12 \times 10^{-5}$ & rs79958058 & $3.12 \times 10^{-5}$ & Fetal placenta & 0.04 \\
\hline
\end{tabular}

Table 3. Number of overlap loci between emphysema apico-basal distribution GWAS, eQTL, and epigenomic marks.

\begin{tabular}{|c|c|c|c|c|}
\hline & \multicolumn{3}{|c|}{ GoShifter } \\
\hline & & $\begin{array}{c}\text { Loci } \\
\text { overlapping any } \\
\text { annotation } \\
\text { (76 loci) }\end{array}$ & $\begin{array}{l}\text { Loci overlapping } \\
\text { any annotation } \\
\text { with cell type P- } \\
\text { value }<0.05 \\
(40 \text { loci })\end{array}$ & $\begin{array}{c}\text { Loci overlapping any annotation } \\
\text { with cell type P-value }<0.05 \text { and } \\
\text { in the lowest } 20 \% \text { of locus score } \\
\text { distributions } \\
\text { (21 loci) }\end{array}$ \\
\hline \multirow{3}{*}{ eQTL } & All GWAS-eQTL overlap loci (54 loci) & 24 & 15 & 6 \\
\hline & $\begin{array}{l}\text { GWAS-eQTL overlap loci with colocalization } \\
\text { probability } \geq 0.5 \text { ( } 22 \text { loci) }\end{array}$ & 11 & 7 & 2 \\
\hline & $\begin{array}{l}\text { GWAS-eQTL overlap loci with colocalization } \\
\text { probability } \geq 0.9 \text { (7 loci) }\end{array}$ & 5 & 4 & 2 \\
\hline
\end{tabular}




\section{FIGURE LEGENDS}

Figure 1. Workflow and summary of the results of the colocalization analysis of emphysema distribution-associated genetic variants with multi-tissue expression quantitative trait loci (eQTL) data from the Genotype-Tissue Expression (GTEx) project and whole blood eQTL from the COPDGene study.

Figure 2. Genome-wide association study (GWAS) and lung expression quantitative trait loci (eQTL) locus plots for rs5758407 variant near the MEII gene (Panel A) and rs7962469 variant near the $A C V R 1 B$ gene (Panel B).

Figure 3. Workflow and summary of the integrative analysis of emphysema distributionassociated genetic variants with DNase-I hypersensitive peaks, DNaseI hotspots, enhancer marks, and digital DNaseI footprints.

Figure 4. Plot of the cell type enrichment $-\log _{10} \mathrm{P}$-value from the Genomic Annotation Shifter (GoShifter) analyses of the overlaps between emphysema distribution-associated genetic variants with DNase-I hypersensitive peaks, DNaseI hotspots, enhancer marks, and digital DNaseI footprints. The cell types with enrichment P-values less than 0.05 are highlighted in red in Figure 4A and are shown in more detail in Figure 4B.

Figure 5. Reporter assays of the rs7962469 variant near the ACVR1B gene in Human Bronchial Epithelial (16HBE) cells showing significantly increased expression of the A variant relative to the $\mathrm{G}$ variant (P-value: 0.008$)$ and the empty Luciferase vector (pGL4.23) (P-value: 0.00002). The P-value comparing the $\mathrm{G}$ variant to pGL4.23 is 0.02 . **: P-value $<0.05$. 


\section{REFERENCES}

1. Celli BR: Roger S. Mitchell lecture. Chronic obstructive pulmonary disease phenotypes and their clinical relevance. Proc Am Thorac Soc 2006, 3(6):461-465.

2. Marsh SE, Travers J, Weatherall M, Williams MV, Aldington S, Shirtcliffe PM, Hansell AL, Nowitz MR, McNaughton AA, Soriano JB, Beasley RW: Proportional classifications of COPD phenotypes. Thorax 2008, 63(9):761-767.

3. de Torres JP, Bastarrika G, Zagaceta J, Saiz-Mendiguren R, Alcaide AB, Seijo LM, Montes U, Campo A, Zulueta JJ: Emphysema presence, severity, and distribution has little impact on the clinical presentation of a cohort of patients with mild to moderate COPD. Chest 2011, 139(1):36-42.

4. Han MK, Bartholmai B, Liu LX, Murray S, Curtis JL, Sciurba FC, Kazerooni EA, Thompson B, Frederick M, Li D, Schwarz M, Limper A, Freeman C, Landreneau RJ, Wise $\mathrm{R}$, Martinez FJ: Clinical significance of radiologic characterizations in COPD. COPD 2009, 6(6):459-467.

5. Venuta F, Anile M, Diso D, Carillo C, De Giacomo T, D'Andrilli A, Fraioli F, Rendina EA, Coloni GF: Long-term follow-up after bronchoscopic lung volume reduction in patients with emphysema. Eur Respir J 2012, 39(5):1084-1089.

6. Deslee G, Mal H, Dutau H, Bourdin A, Vergnon JM, Pison C, Kessler R, Jounieaux V, Thiberville L, Leroy S, Marceau A, Laroumagne S, Mallet JP, Dukic S, Barbe C, Bulsei J, Jolly D, Durand-Zaleski I, Marquette CH, REVOLENS Study Group: Lung Volume Reduction Coil Treatment vs Usual Care in Patients With Severe Emphysema: The REVOLENS Randomized Clinical Trial. JAMA 2016, 315(2):175-184. 
7. Sciurba FC, Chandra D, Bon J: Bronchoscopic Lung Volume Reduction in COPD:

Lessons in Implementing Clinically Based Precision Medicine. JAMA 2016, 315(2):139141.

8. Fishman A, Martinez F, Naunheim K, Piantadosi S, Wise R, Ries A, Weinmann G, Wood DE, National Emphysema Treatment Trial Research Group: A randomized trial comparing lung-volume-reduction surgery with medical therapy for severe emphysema. $N$ Engl $J$ Med 2003, 348(21):2059-2073.

9. Martinez FJ, Foster G, Curtis JL, Criner G, Weinmann G, Fishman A, DeCamp MM, Benditt J, Sciurba F, Make B, Mohsenifar Z, Diaz P, Hoffman E, Wise R, NETT Research Group: Predictors of mortality in patients with emphysema and severe airflow obstruction. Am J Respir Crit Care Med 2006, 173(12):1326-1334.

10. Boueiz A, Lutz SM, Cho MH, Hersh CP, Bowler RP, Washko GR, Halper-Stromberg E, Bakke P, Gulsvik A, Laird NM, Beaty TH, Coxson HO, Crapo JD, Silverman EK, Castaldi PJ, DeMeo DL, COPDGene and ECLIPSE Investigators: Genome-Wide Association Study of the Genetic Determinants of Emphysema Distribution. Am J Respir Crit Care Med 2017, 195(6):757-771.

11. Nicolae DL, Gamazon E, Zhang W, Duan S, Dolan ME, Cox NJ: Trait-associated SNPs are more likely to be eQTLs: annotation to enhance discovery from GWAS. PLoS Genet 2010, 6(4):e1000888.

12. Maurano MT, Humbert R, Rynes E, Thurman RE, Haugen E, Wang H, Reynolds AP, Sandstrom R, Qu H, Brody J, Shafer A, Neri F, Lee K, Kutyavin T, Stehling-Sun S, Johnson AK, Canfield TK, Giste E, Diegel M, Bates D, Hansen RS, Neph S, Sabo PJ, Heimfeld S, Raubitschek A, Ziegler S, Cotsapas C, Sotoodehnia N, Glass I, Sunyaev SR, Kaul R, 
Stamatoyannopoulos JA: Systematic localization of common disease-associated variation in regulatory DNA. Science 2012, 337(6099):1190-1195.

13. ENCODE Project Consortium: An integrated encyclopedia of DNA elements in the human genome. Nature 2012, 489(7414):57-74.

14. Thurman RE, Rynes E, Humbert R, Vierstra J, Maurano MT, Haugen E, Sheffield NC, Stergachis AB, Wang H, Vernot B, Garg K, John S, Sandstrom R, Bates D, Boatman L, Canfield TK, Diegel M, Dunn D, Ebersol AK, Frum T, Giste E, Johnson AK, Johnson EM, Kutyavin T, Lajoie B, Lee BK, Lee K, London D, Lotakis D, Neph S, Neri F, Nguyen ED, Qu H, Reynolds AP, Roach V, Safi A, Sanchez ME, Sanyal A, Shafer A, Simon JM, Song L, Vong S, Weaver M, Yan Y, Zhang Z, Zhang Z, Lenhard B, Tewari M, Dorschner MO, Hansen RS, Navas PA, Stamatoyannopoulos G, Iyer VR, Lieb JD, Sunyaev SR, Akey JM, Sabo PJ, Kaul R, Furey TS, Dekker J, Crawford GE, Stamatoyannopoulos JA: The accessible chromatin landscape of the human genome. Nature 2012, 489(7414):75-82.

15. Trynka G, Westra HJ, Slowikowski K, Hu X, Xu H, Stranger BE, Klein RJ, Han B, Raychaudhuri S: Disentangling the Effects of Colocalizing Genomic Annotations to Functionally Prioritize Non-coding Variants within Complex-Trait Loci. Am J Hum Genet 2015, 97(1):139-152.

16. Cho MH, McDonald ML, Zhou X, Mattheisen M, Castaldi PJ, Hersh CP, Demeo DL, Sylvia JS, Ziniti J, Laird NM, Lange C, Litonjua AA, Sparrow D, Casaburi R, Barr RG, Regan EA, Make BJ, Hokanson JE, Lutz S, Dudenkov TM, Farzadegan H, Hetmanski JB, Tal-Singer R, Lomas DA, Bakke P, Gulsvik A, Crapo JD, Silverman EK, Beaty TH, NETT Genetics, ICGN, ECLIPSE and COPDGene Investigators: Risk loci for chronic obstructive 
pulmonary disease: a genome-wide association study and meta-analysis. Lancet Respir Med 2014, 2(3):214-225.

17. Hormozdiari F, van de Bunt M, Segre AV, Li X, Joo JW, Bilow M, Sul JH, Sankararaman S, Pasaniuc B, Eskin E: Colocalization of GWAS and eQTL Signals Detects Target Genes. Am J Hum Genet 2016, 99(6):1245-1260.

18. Mokry M, Harakalova M, Asselbergs FW, de Bakker PI, Nieuwenhuis EE: Extensive Association of Common Disease Variants with Regulatory Sequence. PLoS One 2016, 11(11):e0165893.

19. Gusev A, Lee SH, Trynka G, Finucane H, Vilhjalmsson BJ, Xu H, Zang C, Ripke S, Bulik-Sullivan B, Stahl E, Schizophrenia Working Group of the Psychiatric Genomics Consortium, SWE-SCZ Consortium, Kahler AK, Hultman CM, Purcell SM, McCarroll SA, Daly M, Pasaniuc B, Sullivan PF, Neale BM, Wray NR, Raychaudhuri S, Price AL, Schizophrenia Working Group of the Psychiatric Genomics Consortium, SWE-SCZ Consortium: Partitioning heritability of regulatory and cell-type-specific variants across 11 common diseases. Am J Hum Genet 2014, 95(5):535-552.

20. Castaldi PJ, Cho MH, Zhou X, Qiu W, Mcgeachie M, Celli B, Bakke P, Gulsvik A, Lomas DA, Crapo JD, Beaty TH, Rennard S, Harshfield B, Lange C, Singh D, Tal-Singer R, Riley JH, Quackenbush J, Raby BA, Carey VJ, Silverman EK, Hersh CP: Genetic control of gene expression at novel and established chronic obstructive pulmonary disease loci. Hum Mol Genet 2015, 24(4):1200-1210.

21. Castaldi PJ, Cho MH, Zhou X, Qiu W, Mcgeachie M, Celli B, Bakke P, Gulsvik A, Lomas DA, Crapo JD, Beaty TH, Rennard S, Harshfield B, Lange C, Singh D, Tal-Singer R, Riley JH, Quackenbush J, Raby BA, Carey VJ, Silverman EK, Hersh CP: Genetic control of 
gene expression at novel and established chronic obstructive pulmonary disease loci. Hum Mol Genet 2015, 24(4):1200-1210.

22. Banovich NE, Lan X, McVicker G, van de Geijn B, Degner JF, Blischak JD, Roux J, Pritchard JK, Gilad Y: Methylation QTLs are associated with coordinated changes in transcription factor binding, histone modifications, and gene expression levels. PLoS Genet 2014, 10(9):e1004663.

23. Ernst J, Kheradpour P, Mikkelsen TS, Shoresh N, Ward LD, Epstein CB, Zhang X, Wang L, Issner R, Coyne M, Ku M, Durham T, Kellis M, Bernstein BE: Mapping and analysis of chromatin state dynamics in nine human cell types. Nature 2011, 473(7345):43-49.

24. Maurano MT, Humbert R, Rynes E, Thurman RE, Haugen E, Wang H, Reynolds AP, Sandstrom R, Qu H, Brody J, Shafer A, Neri F, Lee K, Kutyavin T, Stehling-Sun S, Johnson AK, Canfield TK, Giste E, Diegel M, Bates D, Hansen RS, Neph S, Sabo PJ, Heimfeld S, Raubitschek A, Ziegler S, Cotsapas C, Sotoodehnia N, Glass I, Sunyaev SR, Kaul R, Stamatoyannopoulos JA: Systematic localization of common disease-associated variation in regulatory DNA. Science 2012, 337(6099):1190-1195.

25. Schaub MA, Boyle AP, Kundaje A, Batzoglou S, Snyder M: Linking disease associations with regulatory information in the human genome. Genome Res 2012, 22(9):1748-1759.

26. Fairfax BP, Humburg P, Makino S, Naranbhai V, Wong D, Lau E, Jostins L, Plant K, Andrews $\mathrm{R}$, McGee $\mathrm{C}$, Knight $\mathrm{JC}$ : Innate immune activity conditions the effect of regulatory variants upon monocyte gene expression. Science 2014, 343(6175):1246949. 
27. Boyle EA, Li YI, Pritchard JK: An Expanded View of Complex Traits: From Polygenic to Omnigenic. Cell 2017, 169(7):1177-1186.

28. Chun S, Casparino A, Patsopoulos NA, Croteau-Chonka DC, Raby BA, De Jager PL, Sunyaev SR, Cotsapas C: Limited statistical evidence for shared genetic effects of eQTLs and autoimmune-disease-associated loci in three major immune-cell types. Nat Genet 2017, 49(4):600-605.

29. Giambartolomei C, Vukcevic D, Schadt EE, Franke L, Hingorani AD, Wallace C, Plagnol V: Bayesian test for colocalisation between pairs of genetic association studies using summary statistics. PLoS Genet 2014, 10(5):e1004383.

30. Ito I, Nagai $\mathrm{S}$, Handa $\mathrm{T}$, Muro $\mathrm{S}$, Hirai $\mathrm{T}$, Tsukino $\mathrm{M}$, Mishima M: Matrix metalloproteinase-9 promoter polymorphism associated with upper lung dominant emphysema. Am J Respir Crit Care Med 2005, 172(11):1378-1382.

31. Gurney JW: Cross-sectional physiology of the lung. Radiology 1991, 178(1):1-10.

32. West JB: Distribution of mechanical stress in the lung, a possible factor in localisation of pulmonary disease. Lancet 1971, 1(7704):839-841.

33. DeMeo DL, Hersh CP, Hoffman EA, Litonjua AA, Lazarus R, Sparrow D, Benditt JO, Criner G, Make B, Martinez FJ, Scanlon PD, Sciurba FC, Utz JP, Reilly JJ, Silverman EK: Genetic determinants of emphysema distribution in the national emphysema treatment trial. Am J Respir Crit Care Med 2007, 176(1):42-48.

34. Warburton $\mathrm{D}$, Shi $\mathrm{W}, \mathrm{Xu}$ B: TGF-beta-Smad3 signaling in emphysema and pulmonary fibrosis: an epigenetic aberration of normal development? Am J Physiol Lung Cell Mol Physiol 2013, 304(2):L83-5. 
35. Konigshoff $\mathrm{M}$, Kneidinger $\mathrm{N}$, Eickelberg $\mathrm{O}$ : TGF-beta signaling in COPD: deciphering genetic and cellular susceptibilities for future therapeutic regimen. Swiss Med Wkly 2009, 139(39-40):554-563.

36. McDonald ML, Mattheisen M, Cho MH, Liu YY, Harshfield B, Hersh CP, Bakke P, Gulsvik A, Lange C, Beaty TH, Silverman EK, GenKOLS, COPDGene and ECLIPSE study investigators: Beyond GWAS in COPD: probing the landscape between gene-set associations, genome-wide associations and protein-protein interaction networks. Hum Hered 2014, 78(3-4):131-139.

37. Spira A, Beane JE, Shah V, Steiling K, Liu G, Schembri F, Gilman S, Dumas YM, Calner P, Sebastiani P, Sridhar S, Beamis J, Lamb C, Anderson T, Gerry N, Keane J, Lenburg ME, Brody JS: Airway epithelial gene expression in the diagnostic evaluation of smokers with suspect lung cancer. Nat Med 2007, 13(3):361-366.

38. Wrage M, Ruosaari S, Eijk PP, Kaifi JT, Hollmen J, Yekebas EF, Izbicki JR, Brakenhoff RH, Streichert T, Riethdorf S, Glatzel M, Ylstra B, Pantel K, Wikman H: Genomic profiles associated with early micrometastasis in lung cancer: relevance of $\mathbf{4 q}$ deletion. Clin Cancer Res 2009, 15(5):1566-1574.

39. Sun W, Hu Y: eQTL Mapping Using RNA-seq Data. Stat Biosci 2013, 5(1):10.1007/s12561-012-9068-3. Epub 2012 Jun 9 doi:10.1007/s12561-012-9068-3.

40. Joehanes R, Zhang X, Huan T, Yao C, Ying SX, Nguyen QT, Demirkale CY, Feolo ML, Sharopova NR, Sturcke A, Schaffer AA, Heard-Costa N, Chen H, Liu PC, Wang R, Woodhouse KA, Tanriverdi K, Freedman JE, Raghavachari N, Dupuis J, Johnson AD, O'Donnell CJ, Levy D, Munson PJ: Integrated genome-wide analysis of expression 
quantitative trait loci aids interpretation of genomic association studies. Genome Biol 2017, 18(1):16-016-1142-6.

41. Cho MH, Castaldi PJ, Hersh CP, Hobbs BD, Barr RG, Tal-Singer R, Bakke P, Gulsvik A, San Jose Estepar R, Van Beek EJ, Coxson HO, Lynch DA, Washko GR, Laird NM, Crapo JD, Beaty TH, Silverman EK, NETT Genetics, ECLIPSE, and COPDGene Investigators: A Genome-wide Association Study of Emphysema and Airway Quantitative Imaging Phenotypes. Am J Respir Crit Care Med 2015, :.

42. Coxson HO, Rogers RM, Whittall KP, D'yachkova Y, Pare PD, Sciurba FC, Hogg JC: A quantification of the lung surface area in emphysema using computed tomography. $A m$ J Respir Crit Care Med 1999, 159(3):851-856.

43. Jiang H, Lei R, Ding SW, Zhu S: Skewer: a fast and accurate adapter trimmer for next-generation sequencing paired-end reads. BMC Bioinformatics 2014, 15:182-2105-15182.

44. Dobin A, Davis CA, Schlesinger F, Drenkow J, Zaleski C, Jha S, Batut P, Chaisson M, Gingeras TR: STAR: ultrafast universal RNA-seq aligner. Bioinformatics 2013, 29(1):1521.

45. Liao Y, Smyth GK, Shi W: The Subread aligner: fast, accurate and scalable read mapping by seed-and-vote. Nucleic Acids Res 2013, 41(10):e108.

46. DeLuca DS, Levin JZ, Sivachenko A, Fennell T, Nazaire MD, Williams C, Reich M, Winckler W, Getz G: RNA-SeQC: RNA-seq metrics for quality control and process optimization. Bioinformatics 2012, 28(11):1530-1532. 
47. Robinson MD, Oshlack A: A scaling normalization method for differential expression analysis of RNA-seq data. Genome Biol 2010, 11(3):R25-2010-11-3-r25. Epub 2010 Mar 2.

48. Stegle O, Parts L, Durbin R, Winn J: A Bayesian framework to account for complex non-genetic factors in gene expression levels greatly increases power in eQTL studies. PLoS Comput Biol 2010, 6(5):e1000770.

49. Shabalin AA: Matrix eQTL: ultra fast eQTL analysis via large matrix operations. Bioinformatics 2012, 28(10):1353-1358.

50. Storey JD, Tibshirani R: Statistical significance for genomewide studies. Proc Natl Acad Sci U S A 2003, 100(16):9440-9445.

51. Roadmap Epigenomics Consortium, Kundaje A, Meuleman W, Ernst J, Bilenky M, Yen A, Heravi-Moussavi A, Kheradpour P, Zhang Z, Wang J, Ziller MJ, Amin V, Whitaker JW, Schultz MD, Ward LD, Sarkar A, Quon G, Sandstrom RS, Eaton ML, Wu YC, Pfenning AR, Wang X, Claussnitzer M, Liu Y, Coarfa C, Harris RA, Shoresh N, Epstein CB, Gjoneska E, Leung D, Xie W, Hawkins RD, Lister R, Hong C, Gascard P, Mungall AJ, Moore R, Chuah E, Tam A, Canfield TK, Hansen RS, Kaul R, Sabo PJ, Bansal MS, Carles A, Dixon JR, Farh KH, Feizi S, Karlic R, Kim AR, Kulkarni A, Li D, Lowdon R, Elliott G, Mercer TR, Neph SJ, Onuchic V, Polak P, Rajagopal N, Ray P, Sallari RC, Siebenthall KT, Sinnott-Armstrong NA, Stevens M, Thurman RE, Wu J, Zhang B, Zhou X, Beaudet AE, Boyer LA, De Jager PL, Farnham PJ, Fisher SJ, Haussler D, Jones SJ, Li W, Marra MA, McManus MT, Sunyaev S, Thomson JA, Tlsty TD, Tsai LH, Wang W, Waterland RA, Zhang MQ, Chadwick LH, Bernstein BE, Costello JF, Ecker JR, Hirst M, Meissner A, Milosavljevic A, Ren B, Stamatoyannopoulos JA, Wang T, Kellis M: Integrative analysis of 111 reference human epigenomes. Nature 2015, 518(7539):317-330. 
52. Ernst J, Kellis M: Large-scale imputation of epigenomic datasets for systematic annotation of diverse human tissues. Nat Biotechnol 2015, 33(4):364-376.

53. John S, Sabo PJ, Thurman RE, Sung MH, Biddie SC, Johnson TA, Hager GL, Stamatoyannopoulos JA: Chromatin accessibility pre-determines glucocorticoid receptor binding patterns. Nat Genet 2011, 43(3):264-268.

54. Farh KK, Marson A, Zhu J, Kleinewietfeld M, Housley WJ, Beik S, Shoresh N, Whitton H, Ryan RJ, Shishkin AA, Hatan M, Carrasco-Alfonso MJ, Mayer D, Luckey CJ, Patsopoulos NA, De Jager PL, Kuchroo VK, Epstein CB, Daly MJ, Hafler DA, Bernstein BE: Genetic and epigenetic fine mapping of causal autoimmune disease variants. Nature 2015, 518(7539):337-343.

\section{DECLARATIONS}

\section{Ethics approval and consent to participate}

Informed consent was obtained from all study subjects and study approval was obtained from institutional review boards for all participating institutions.

\section{Availability of data and material}

COPDGene data are available in the NCBI dbGaP database of genotypes and phenotypes under accession number phs000179.v1.p1.

\section{Competing interests}

Dr. Hersh reports personal fees from AstraZeneca, grants from Boehringer Ingelheim, personal fees from Mylan, personal fees from Concert Pharmaceuticals which are outside the submitted work. Dr. Cho reports grants from GSK, grants from NIH / NHLBI during the 
conduct of the study. Dr. DeMeo reports grants from NIH, personal fees from Novartis outside the submitted work. Dr. Silverman reports grants from NIH during the conduct of the study, personal fees from Novartis, and grant and travel support from GlaxoSmithKline outside the submitted work. Dr. Castaldi reports grants and Advisory Board membership from GSK outside the submitted work. All the other authors have no conflict of interest or financial relationships to disclose. No form of payment was given to anyone to produce the manuscript.

\section{Consent for publication}

Not applicable.

\section{Funding}

This work was supported by NHLBI R01HL089897, R01HL089856, R01HL124233, R01HL126596, R01HL113264, P01105339, P01HL114501 and K12HL120004-05. The COPDGene study (NCT00608764) is also supported by the COPD Foundation through contributions made to an Industry Advisory Board comprised of AstraZeneca, Boehringer Ingelheim, Novartis, Pfizer, GlaxoSmithKline, Siemens and Sunovion. The Norway GenKOLS (Genetics of Chronic Obstructive Lung Disease, GSK code RES11080) and the ECLIPSE studies (NCT00292552; GSK code SCO104960) were funded by GlaxoSmithKline.

\section{Authors' contributions}

Dr. Castaldi had full access to all of the data in the study, takes responsibility for the integrity of the data and the accuracy of the data analysis, had authority over manuscript preparation and the decision to submit the manuscript for publication.

Study concept and design: Boueiz, Castaldi

Acquisition, analysis, or interpretation of data: All authors 
Drafting of the manuscript: Boueiz, Castaldi

Critical revision of the manuscript for important intellectual content: All authors

Statistical analysis: Boueiz, Castaldi

Obtained funding: Castaldi, Crapo, Silverman

Study supervision: All authors

All authors gave final approval of the version to be published and have agreed to be accountable for all aspects of the work.

\section{Acknowledgements}

\section{COPDGene Investigators - Core Units:}

Administrative Core: James Crapo, MD (PI), Edwin Silverman, MD, PhD (PI), Barry Make, MD, Elizabeth Regan, MD, PhD

Genetic Analysis Core: Terri Beaty, PhD, Nan Laird, PhD, Christoph Lange, PhD, Michael Cho, MD, Stephanie Santorico, PhD, John Hokanson, MPH, PhD, Dawn DeMeo, MD, MPH, Nadia Hansel, MD, MPH, Craig Hersh, MD, MPH, Peter Castaldi, MD, MSc, Merry-Lynn McDonald, PhD, Emily Wan, MD, Megan Hardin, MD, Jacqueline Hetmanski, MS, Margaret Parker, MS, Marilyn Foreman, MD, Brian Hobbs, MD, Adel Boueiz, MD, Peter Castaldi, MD, Megan Hardin, MD, Dandi Qiao, PhD, Elizabeth Regan, MD, Eitan Halper-Stromberg, Ferdouse Begum, Sungho Won, Sharon Lutz, PhD

Imaging Core: David A Lynch, MB, Harvey O Coxson, PhD, MeiLan K Han, MD, MS, MD, Eric A Hoffman, PhD, Stephen Humphries MS, Francine L Jacobson, MD, Philip F Judy, PhD, Ella A Kazerooni, MD, John D Newell, Jr., MD, Elizabeth Regan, MD, James C Ross, PhD, Raul San Jose Estepar, PhD, Berend C Stoel, PhD, Juerg Tschirren, PhD, Eva van Rikxoort, PhD, Bram van Ginneken, PhD, George Washko, MD, Carla G Wilson, MS, Mustafa Al Qaisi, MD, Teresa Gray, Alex Kluiber, Tanya Mann, Jered Sieren, Douglas Stinson, Joyce Schroeder, MD, Edwin Van Beek, MD, PhD 
PFT QA Core, Salt Lake City, UT: Robert Jensen, $\mathrm{PhD}$

Data Coordinating Center and Biostatistics, National Jewish Health, Denver, CO: Douglas Everett, $\mathrm{PhD}$, Anna Faino, MS, Matt Strand, PhD, Carla Wilson, MS

Epidemiology Core, University of Colorado Anschutz Medical Campus, Aurora, CO: John E. Hokanson, MPH, PhD, Gregory Kinney, MPH, PhD, Sharon Lutz, PhD, Kendra Young PhD, Katherine Pratte, MSPH, Lindsey Duca, MS.

\section{COPDGene Investigators - Clinical Centers:}

Ann Arbor VA: Jeffrey L. Curtis, MD, Carlos H. Martinez, MD, MPH, Perry G. Pernicano, MD

Baylor College of Medicine, Houston, TX: Nicola Hanania, MD, MS, Philip Alapat, MD, Venkata Bandi, MD, Mustafa Atik, MD, Aladin Boriek, PhD, Kalpatha Guntupalli, MD, Elizabeth Guy, MD, Amit Parulekar, MD, Arun Nachiappan, MD

Brigham and Women's Hospital, Boston, MA: Dawn DeMeo, MD, MPH, Craig Hersh, MD, MPH, George Washko, MD, Francine Jacobson, MD, MPH

Columbia University, New York, NY: R. Graham Barr, MD, DrPH, Byron Thomashow, MD, John Austin, MD, Belinda D’Souza, MD, Gregory D.N. Pearson, MD, Anna Rozenshtein, MD, MPH, FACR

Duke University Medical Center, Durham, NC: Neil MacIntyre, Jr., MD, Lacey Washington, MD, H. Page McAdams, MD

Health Partners Research Foundation, Minneapolis, MN: Charlene McEvoy, MD, MPH, Joseph Tashjian, MD

Johns Hopkins University, Baltimore, MD: Robert Wise, MD, Nadia Hansel, MD, MPH, Robert Brown, MD, Karen Horton, MD, Nirupama Putcha, MD, MHS, 
Los Angeles Biomedical Research Institute at Harbor UCLA Medical Center, Torrance, CA: Richard Casaburi, PhD, MD, Alessandra Adami, PhD, Janos Porszasz, MD, PhD, Hans Fischer, MD, PhD, Matthew Budoff, MD, Harry Rossiter, $\mathrm{PhD}$

Michael E. DeBakey VAMC, Houston, TX: Amir Sharafkhaneh, MD, PhD, Charlie Lan, DO Minneapolis VA: Christine Wendt, MD, Brian Bell, MD

Morehouse School of Medicine, Atlanta, GA: Marilyn Foreman, MD, MS, Gloria Westney, MD, MS, Eugene Berkowitz, MD, PhD

National Jewish Health, Denver, CO: Russell Bowler, MD, PhD, David Lynch, MD

Reliant Medical Group, Worcester, MA: Richard Rosiello, MD, David Pace, MD

Temple University, Philadelphia, PA: Gerard Criner, MD, David Ciccolella, MD, Francis Cordova, MD, Chandra Dass, MD, Gilbert D’Alonzo, DO, Parag Desai, MD, Michael Jacobs, PharmD, Steven Kelsen, MD, PhD, Victor Kim, MD, A. James Mamary, MD, Nathaniel Marchetti, DO, Aditi Satti, MD, Kartik Shenoy, MD, Robert M. Steiner, MD, Alex Swift, MD, Irene Swift, MD, Maria Elena Vega-Sanchez, MD

University of Alabama, Birmingham, AL: Mark Dransfield, MD, William Bailey, MD, J. Michael Wells, MD, Surya Bhatt, MD, Hrudaya Nath, MD

University of California, San Diego, CA: Joe Ramsdell, MD, Paul Friedman, MD, Xavier Soler, MD, PhD, Andrew Yen, MD

University of Iowa, Iowa City, IA: Alejandro Cornellas, MD, John Newell, Jr., MD, Brad Thompson, MD

University of Michigan, Ann Arbor, MI: MeiLan Han, MD, Ella Kazerooni, MD, Carlos Martinez, MD

University of Minnesota, Minneapolis, MN: Joanne Billings, MD, Tadashi Allen, MD University of Pittsburgh, Pittsburgh, PA: Frank Sciurba, MD, Divay Chandra, MD, MSc, Joel Weissfeld, MD, MPH, Carl Fuhrman, MD, Jessica Bon, MD 
bioRxiv preprint doi: https://doi.org/10.1101/189100; this version posted September 22, 2017. The copyright holder for this preprint (which was not certified by peer review) is the author/funder. All rights reserved. No reuse allowed without permission.

University of Texas Health Science Center at San Antonio, San Antonio, TX: Antonio Anzueto, MD, Sandra Adams, MD, Diego Maselli-Caceres, MD, Mario E. Ruiz, MD 
Figure 1

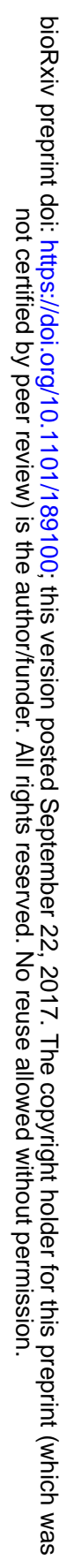




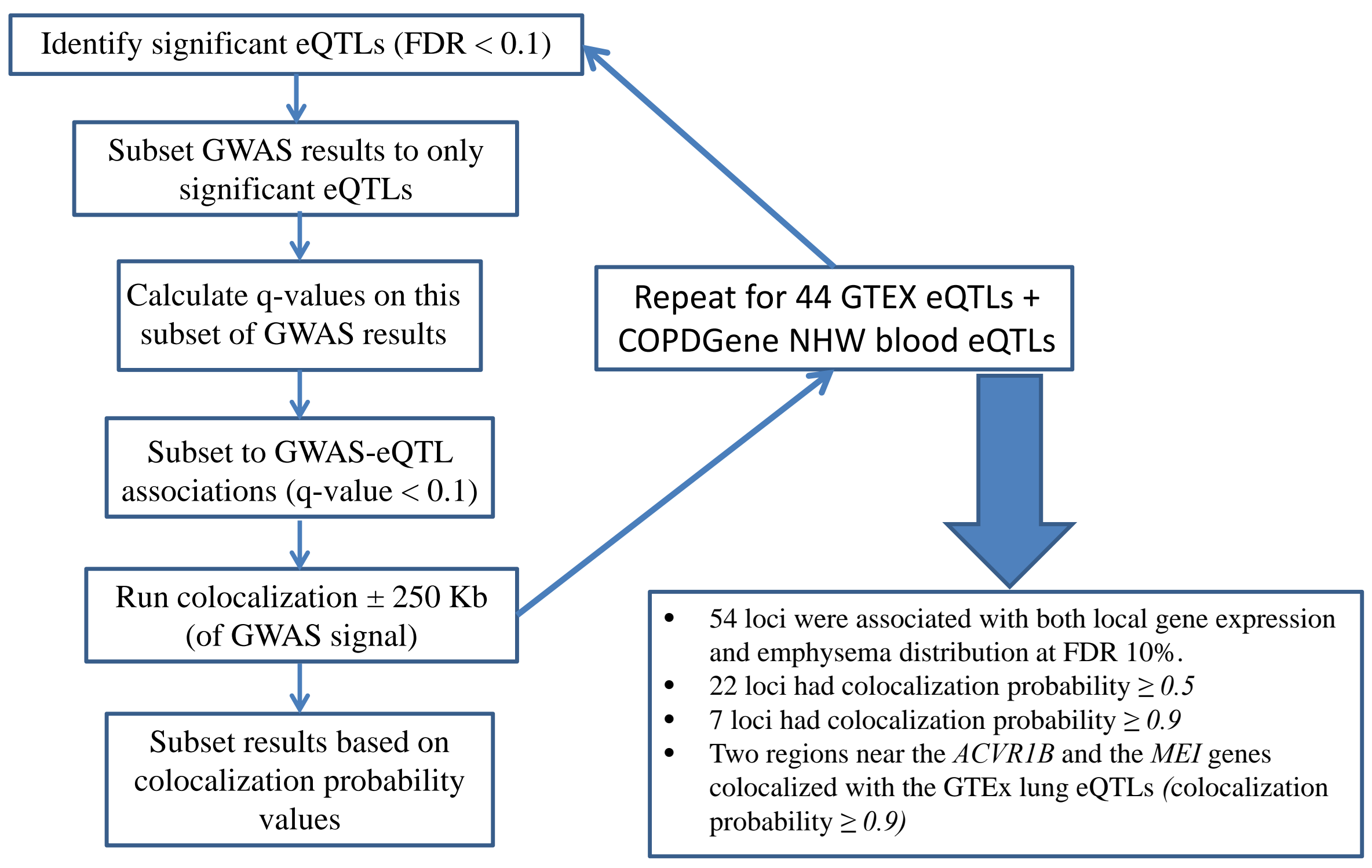


Figure 2

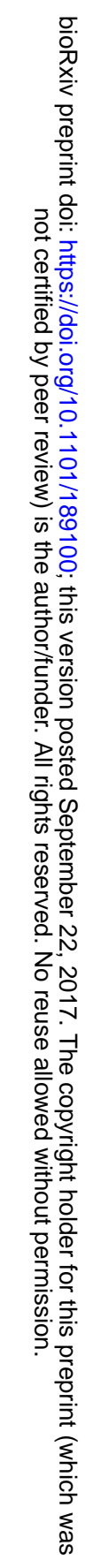


Panel A

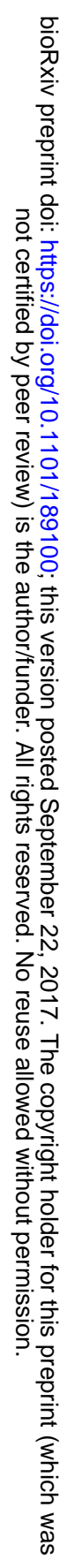




\section{rs5758407 variant near the MEI1 gene}

\section{GWAS}

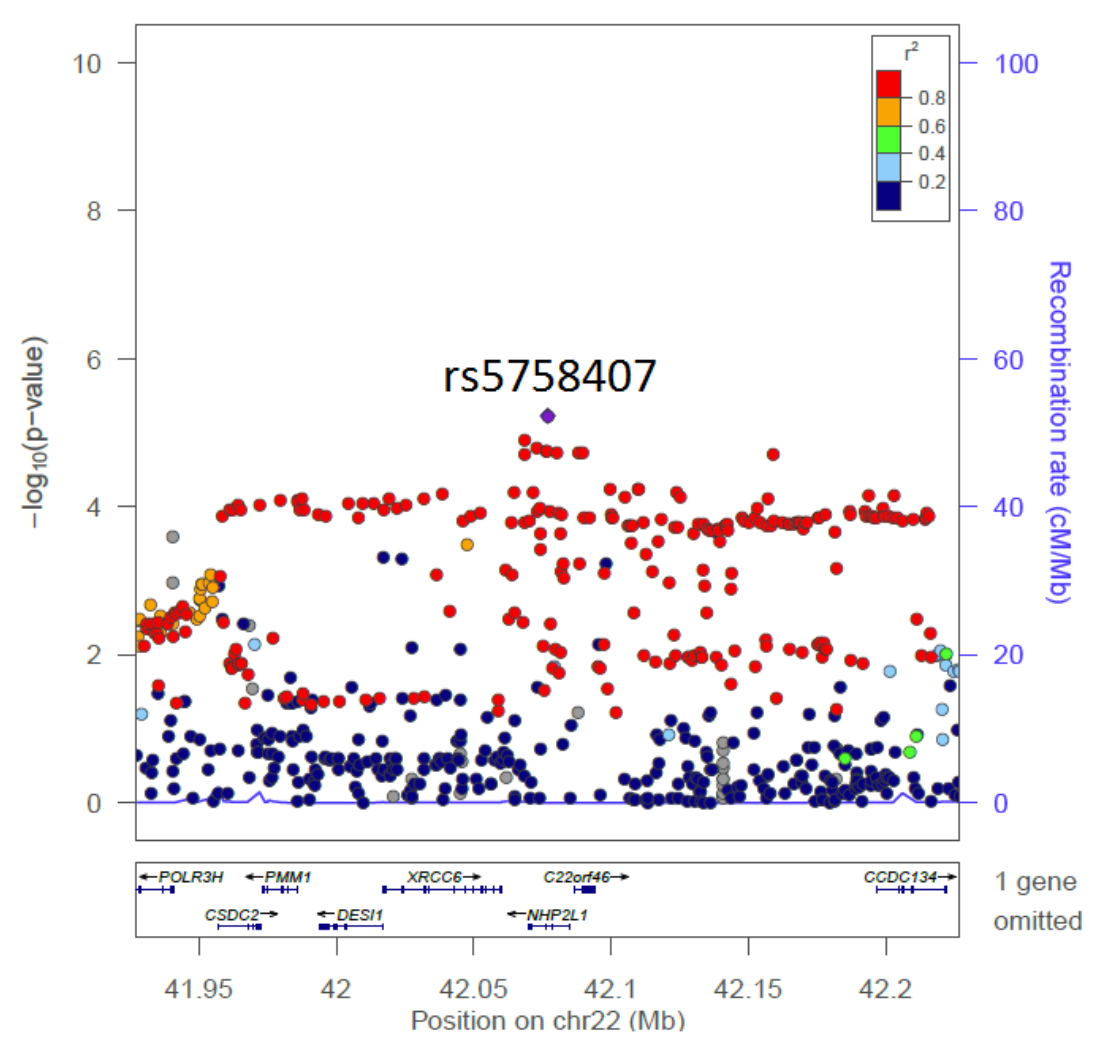

Lung eQTL

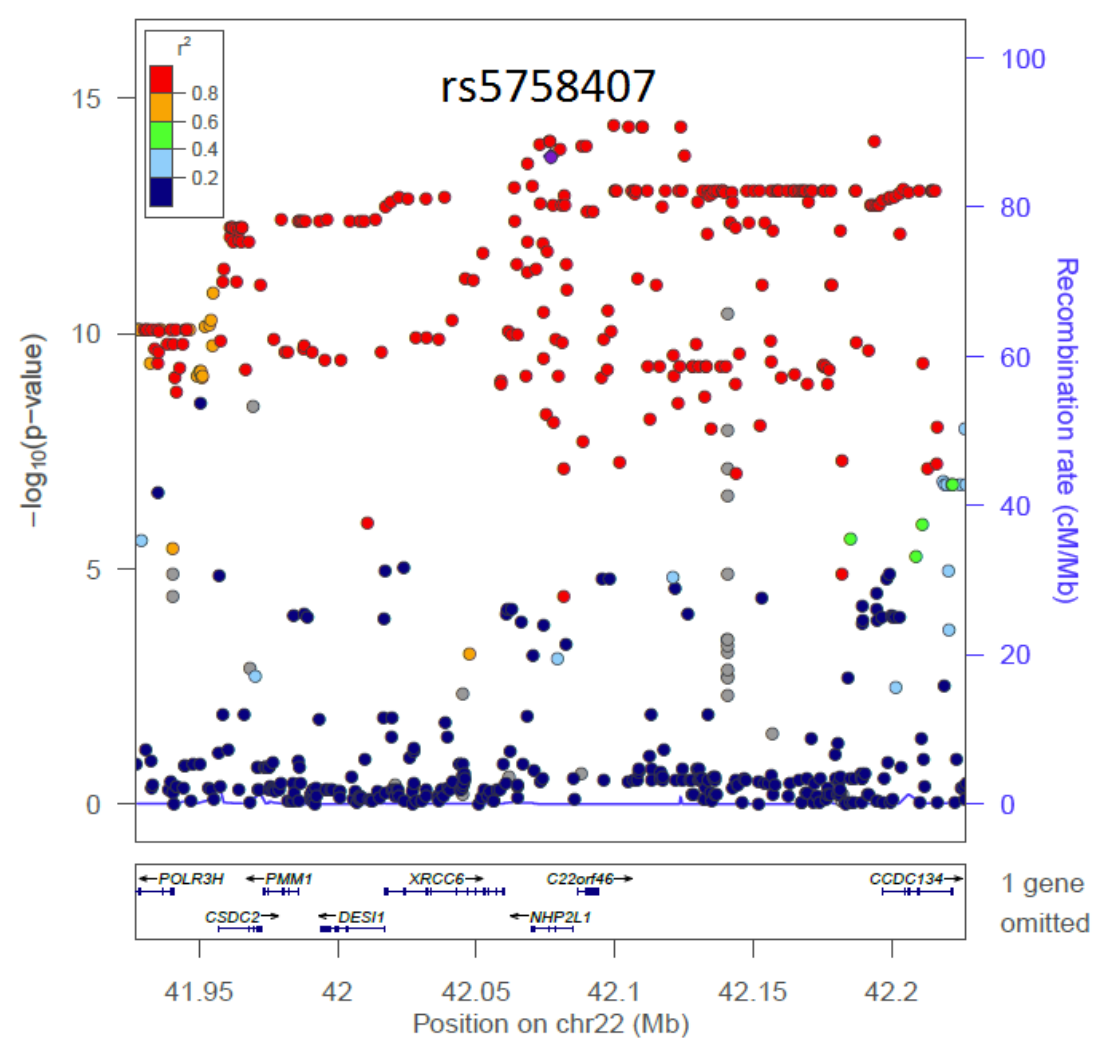


Panel B

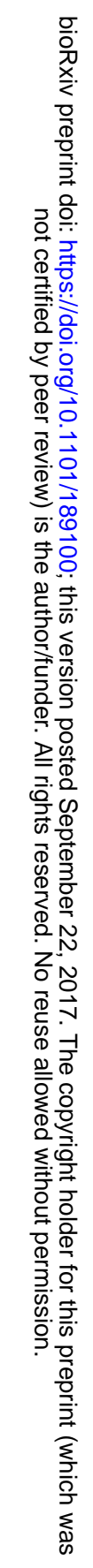




\section{rs7962469 variant near the $A C V R 1 B$ gene}
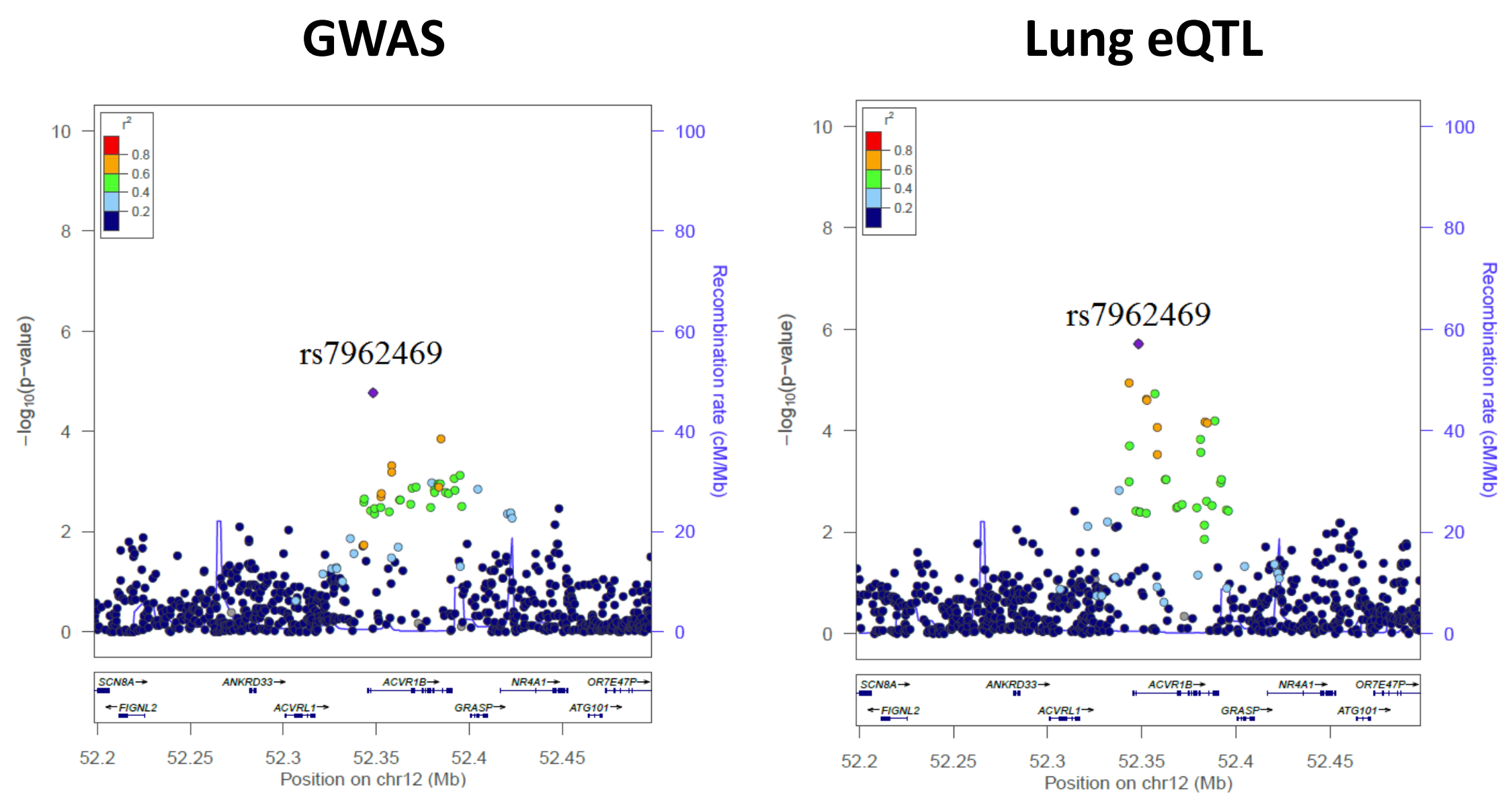
Figure 3

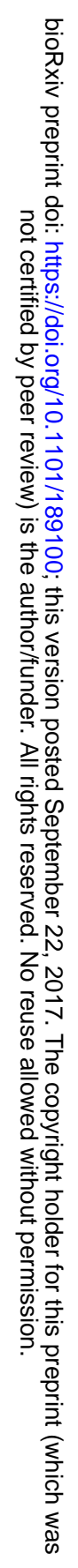


Emphysema distribution associated loci:

- 168 independent loci associated with emphysema distribution at GWAS P-value < $5 \times 10^{-5}$ (Boueiz et al, AJRCCM 2017)

- Identify all variants in LD with each emphysema distribution index SNP $\left(r^{2}>0.8\right.$ in the 1,000 Genomes Project European samples) $\rightarrow$ Total of 2,033 SNPs

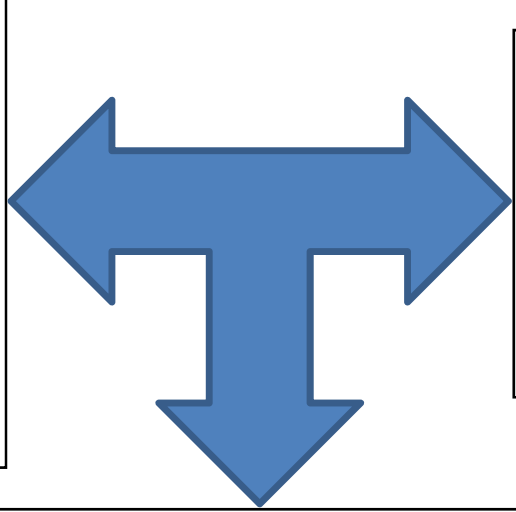

Epigenetic annotations:

- ChromImpute DNase-I hypersensitive sites (DHS peaks and hotspots)

- Enhancer marks (ChromImpute chromatin states 13 -18)

- Digital DNaseI footprints

Find overlap:

- For each annotation, identify instances of overlap with emphysema distribution-associated SNPs.

o 48 loci overlapped with DHS peaks

o 54 loci overlapped with DHS hotspots

o 60 loci overlapped with enhancer marks

o 26 loci overlapped with DNaseI footprints

o 76 loci overlapped with at least one annotation

$\underline{\text { Test significance of overlap: }}$

- For each annotation, assess significance of overlap via local permutations using GoShifter.

o 17 cell types had significant enrichment of GWAS loci in at least one annotation (cell-type enrichment $P$-value < 0.05)

\section{Prioritizing informative loci:}

- For each annotation, overlaps in the lowest $20 \%$ of locus score distributions and with a cell type enrichment P-value $<0.05$ were considered for further analysis.

o 5 loci overlapped with DHS peaks in 9 cell types

o 8 loci overlapped with DHS hotspots in 3 cell types

o 15 loci overlapped with enhancer marks in 3 cell types

o 4 loci overlapped with DNaseI footprints in 3 cell types

o 21 loci overlapped with at least one annotation in 17 cell types 
Figure 4

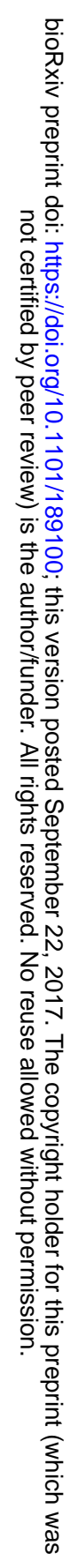


4A 


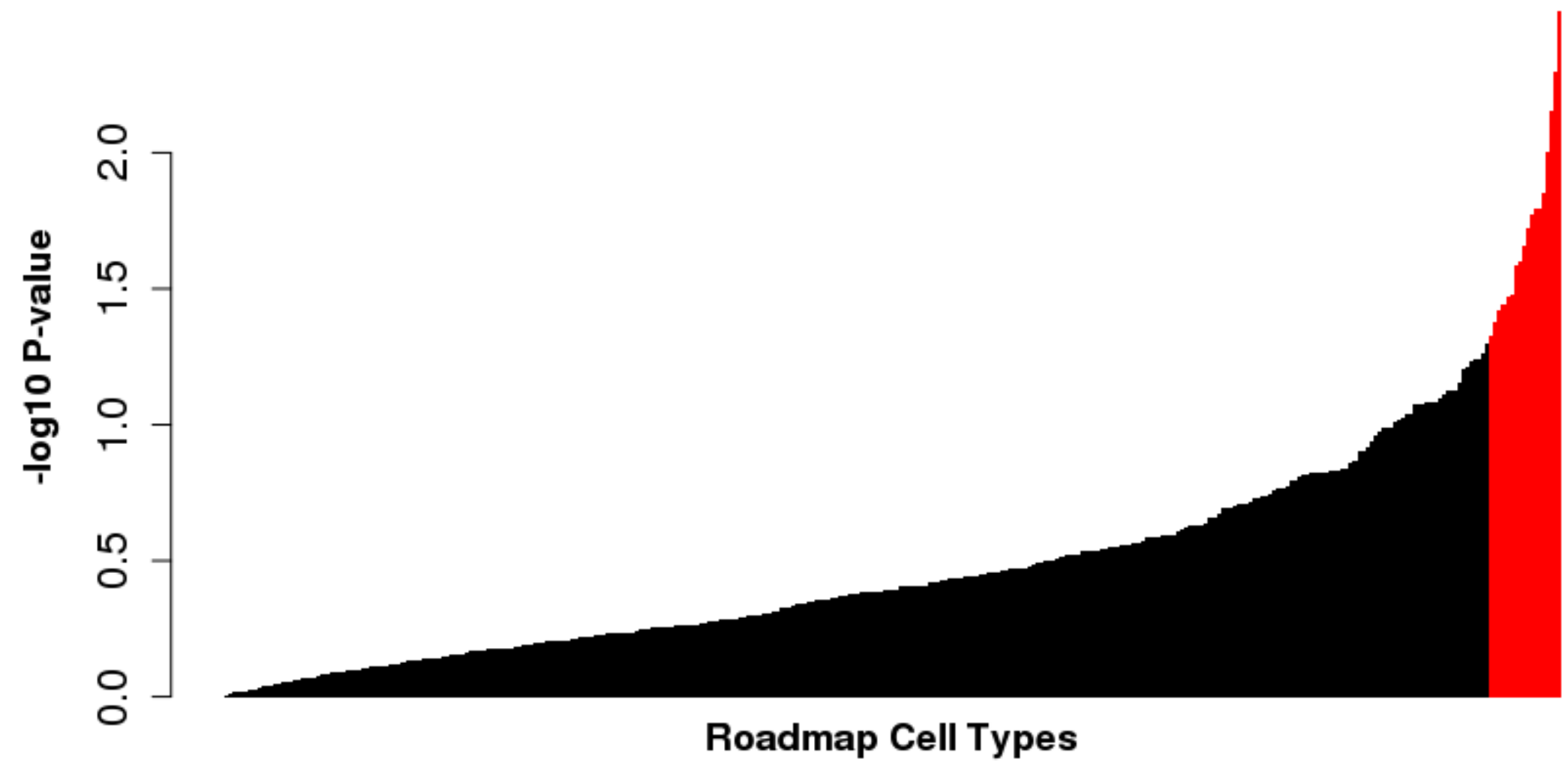


4B 
Primary Thelper 17 cells PMA-I stimulated

Primary T cells effector/memory enriched from peripheral blood

Primary T cells from peripheral blood

\section{Fetal Heart}

Primary T killer memory cells from peripheral blood

Primary T helper memory cells from peripheral blood I

Primary Thelper naive cells from peripheral blood

Primary T helper cells PMA-I stimulated

Primary T helper naive cells from peripheral blood

Primary T cells from peripheral blood

iPS 19.11

Fetal skin fibroblast

Primary T regulatory cells from peripheral blood

Thymus

Fetal placenta

Small intestine

Primary Natural Killer cells from peripheral blood

ES-WA7 Cell Line

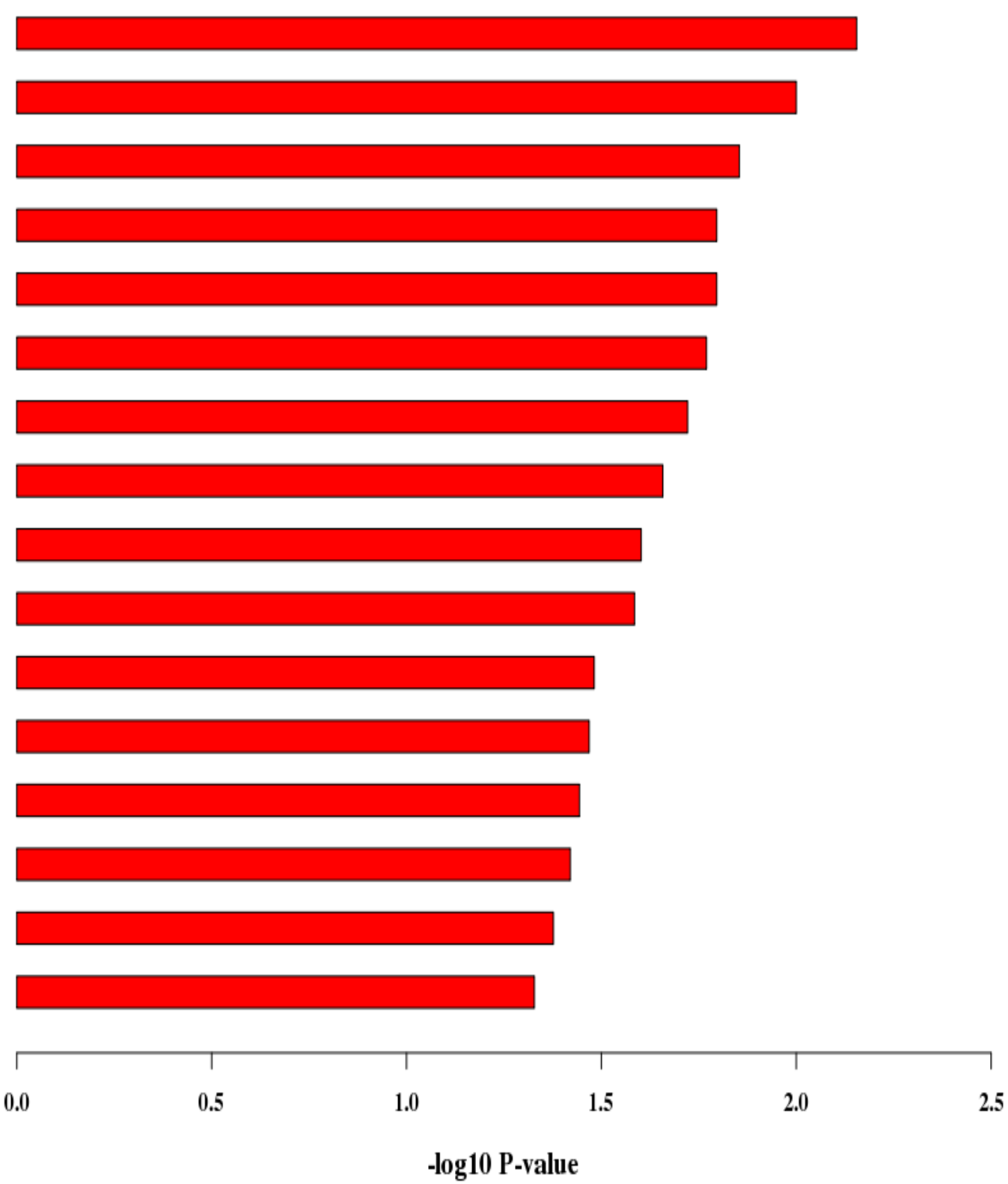

- $\log 10$ P-value 
Figure 5

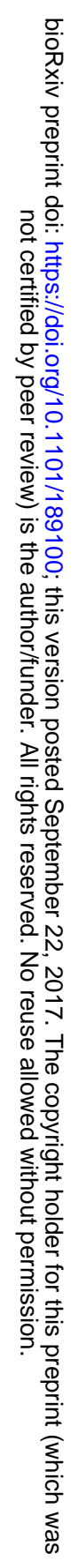




\section{ACVR1B SNPs luciferase activity - 16HBE}

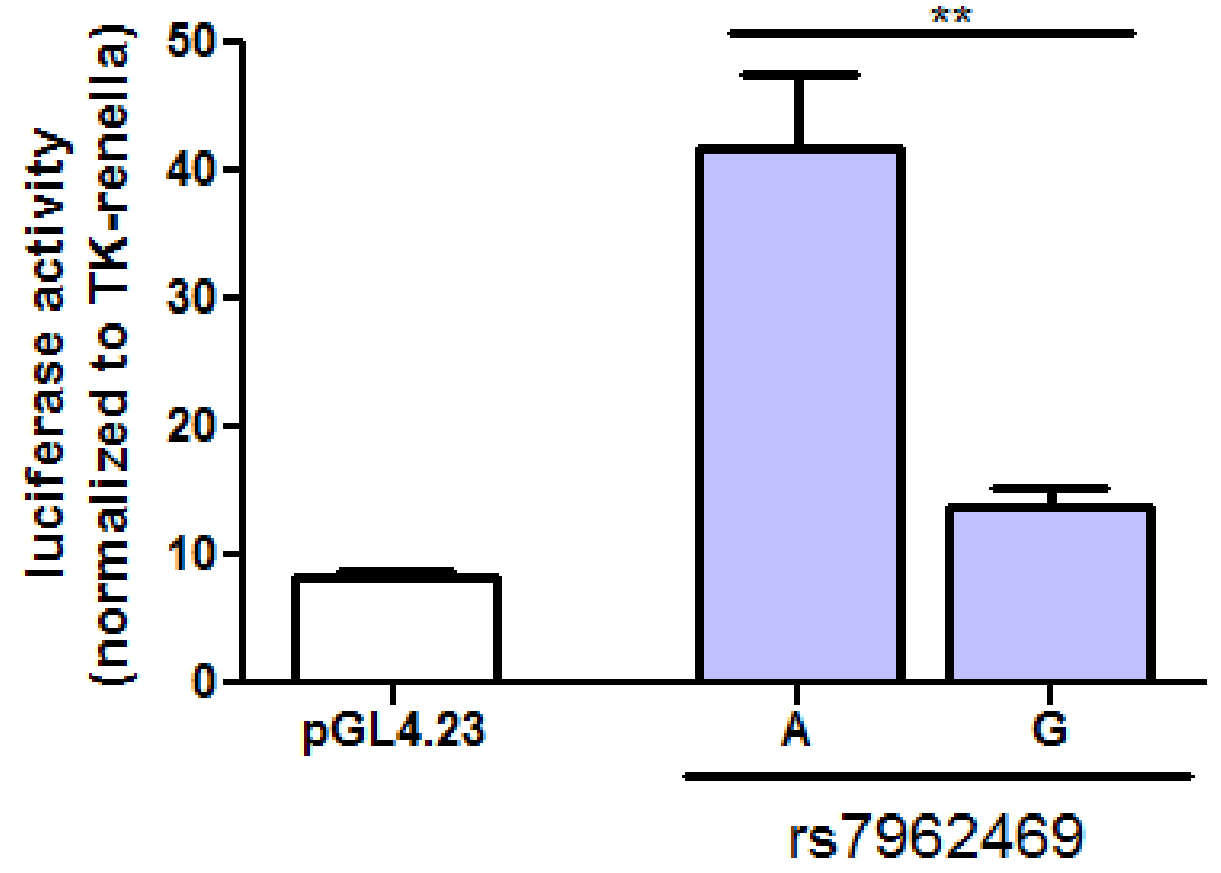

